\title{
Contribution of organic farming to public goods in Denmark
}

\author{
Lizzie Melby Jespersen • Dorte Lau Baggesen • Erik Fog • Kirsten Halsnæes • \\ John Erik Hermansen • Lise Andreasen • Beate Strandberg • Jan Tind Sørensen • \\ Niels Halberg
}

Received: 10 May 2017 / Accepted: 16 August 2017 / Published online: 29 August 2017

(C) The Author(s) 2017. This article is an open access publication

\begin{abstract}
The potential contribution of organic farming to the public goods, 'Nature and Biodiversity', 'Environment', 'Energy and Climate', 'Human Health and Welfare' and 'Animal Health and Welfare' in Denmark is guided and partly secured by the principles and specific requirements of the EU Organic Regulation. However, other factors, such as the production type, farm size, geographical location and - not the least - the management of the farm, also influence the contribution. Using the ban on synthetic pesticides and restricted use of antibiotics, including the requirements to compensate for and prevent such uses in organic farming, as examples, the positive and negative contributions of organic farming in relation to selected public goods were analysed. The contributions of organic farming to Nature and Biodiversity and Human and Animal Health and
\end{abstract}

\section{M. Jespersen}

International Centre for Research in Organic Food Systems (ICROFS), Blichers Allé 20, 8830 Tjele, Denmark

\section{L. Baggesen}

National Food Institute, Technical University of Denmark, Kemitorvet, Bld. 204, 2800 Kgs. Lyngby, Denmark

E. Fog

SEGES, Agro Food Park 15, 8200 Aarhus N, Denmark

\section{K. Halsnæs}

DTU Management Engineering, Technical University of Denmark, Produktionstorvet, Bld. 426, 2800 Kgs. Lyngby, Denmark
Welfare are mainly positive compared to conventional farming for all farm types, whilst the effects on Environment and Energy and Climate are mixed; i.e. some effects are positive and others are negative. The analysis revealed a need for further documentation and revision of the organic principles and specific organic requirementsin particular in relation to the public goods Energy and Climate, which at present are not addressed in the EU Organic Regulation. Moreover, some organic farming requirements and practices cause dilemmas; e.g. more space per animal and outdoor access improves Animal Health and Welfare but at the same time has negative effects on Environment, Energy Consumption and Climate Change. These dilemmas should be solved before OA may be fully attractive as an integrated policy measure supporting jointly several public goods objectives.

\footnotetext{
J. E. Hermansen

Department of Agroecology, Aarhus University, Blichers Allé 20, 8830 Tjele, Denmark

L. Andreasen $\cdot$ N. Halberg $(\bowtie)$

International Centre for Research in Organic Food Systems

(ICROFS), Blichers Allé 20, 8830 Tjele, Denmark

e-mail: Niels.Halberg@icrofs.org

B. Strandberg

Department of Animal Science, Aarhus University, Blichers Allé 20, 8830 Tjele, Denmark

J. T. Sørensen

Department of Bioscience, Aarhus University, Vejlsøvej 25, Bld. C3.20, 8600 Silkeborg, Denmark
} 
Keywords Organic agriculture · Public goods · Knowledge synthesis · Pesticides · Antibiotics . Organic regulation

\section{Introduction}

According to the Preamble of Council Regulation (EC) $834 / 2007$ on organic production, Preamble 1 (EU Reg. $834 / 2007$ ), organic production is defined as 'an overall system of farm management and food production that combines best environmental practices, a high level of biodiversity, the preservation of natural resources, the application of high animal welfare standards and a production method in line with the preference of certain consumers for products produced using natural substances and processes. The organic production method thus plays a dual societal role, where it on the one hand provides for a specific market responding to a consumer demand for organic products, and on the other hand delivers public goods contributing to the protection of the environment and animal welfare, as well as to rural development'.

The (EC) anticipation that organic agriculture contributes with organic food products of high quality to a consumer-driven market on the one hand as well as delivers public goods to society on the other hand are the main reasons why organic farming is specifically recognised in the Common Agricultural Policy (CAP) of the European Union (EU) for the period of 20142020 (European Commission 2017a). In the first pillar (focusing on income support to farmers linked with certain requirements for environment, animal welfare and food safety), organic farms benefit from the so-called green direct payments (European Commission 2017b) without a requirement to fulfil any further obligations because of their overall contribution to environmental objectives (EU Reg. 1307/2013). Under pillar 2, which deals with support to rural development implemented by the Member States, the importance of organic farming is stressed through the creation of a separate 'organic farming measure' support programme (EU Reg. 1305/2013). These policy-driven expectation to organic agriculture is one motivation for this paper, which aims at critically reviewing to what extent this can be documented.

Public goods

Agriculture can bring both positive and negative impacts on the environment and society. These externalities from agricultural activities may have characteristics of non-rivalry and non-excludability. When goods satisfy the two criteria of being non-excludable, they are defined as public goods (Samuelson 1954, 1955). In reality, few products fully meet these criteria and may only to a certain extent be excludable and/or rival-sometimes referred to as 'impure public goods'. Therefore, in this study, we define 'public goods', based on Web Finance Inc. (2017), as 'goods or services that society wants its citizens to have access to, but which are normally not tradeable and non-excludable'. The value of public goods resulting from farming is most often not reflected in agricultural commodities. Thus, the prices do not convey the value of public goods. This may result in under- or over-supply of a public good. When the market does not by itself produce such public goods in sufficient amounts, public policies may be needed in order to ensure a high quality of public goods and to reduce negative externalities as, e.g. pollution of the environment from agricultural practices (OECD 2015). Thus, public goods are often protected or enforced by legislation, which may be supported by public spending/ taxation. As examples can be mentioned, biodiversity and water protection support measures under the CAP (European Commission 2017a, b), measures to mitigate climate change, protection of human and animal health and welfare, etc. Organic farming potentially contributes to a range of public goods, because its overall aim is to develop sustainable agriculture as formulated in the four basic principles on Ecology, Health, Fairness and Care of IFOAM (IFOAM 2005). The EU Organic Regulation (EU Reg. 834/2007) includes the organic principles in Articles 3-7 and aims to secure their implementation through specific rules.

\section{Regulation of organic farming in Denmark}

Denmark has state regulation and control of organic farming (Landbrugs- og Fiskeristyrelsen 2017). This means that the Council Regulation (EC) No. 834/2007 and the Commission Regulation (EC) No. 889/2008 apply together with Danish guidelines - i.e. interpretations of the EU Organic Regulation (Landbrugs- og Fiskeristyrelsen 2017). Denmark also has a regulation on organic cuisine labelling, and the labels in gold (90$100 \%$ organic), silver (60-90\% organic) or bronze (30$60 \%$ organic) have been obtained by 1862 restaurants, canteens and public kitchens by January 2017 (Fødevarestyrelsen 2017). Organic farming is also 
regulated indirectly by EU Reg. 1305/2013 on support for rural development. In Denmark, the limit for obtaining basic organic support is maximum $100 \mathrm{~kg}$ utilisable $\mathrm{N} /$ ha on average, which may be supplemented with an extra payment on top, if the maximum limit is reduced to $60 \mathrm{~kg}$ utilisable N/ha on average (Landbrugsog Fiskeristyrelsen 2017). Besides, the private organic industry organisations for cattle and pigs have set up some extra rules to improve animal health and welfare beyond the requirements of the EU organic regulation. The Danish control logo is the red ' $\varnothing$ ' label (organic is called Økologisk in Danish), which has very high credibility amongst Danish consumers and is known by all Danes (Miljø- og Fødevareministeriet 2016a).

\section{Status of organic farming in Denmark}

The development of organic farming in Denmark has partly been market driven and partly pushed by public organic action plans and support measures (Halberg et al. 2008a; Jensen and Pedersen 2015). The consumption and export of organic food products have increased dramatically in recent years (Jensen and Pedersen 2015). Danish retail trade has one of the highest organic market shares in the world with $8 \%$ in 2015 corresponding to approximately 7 billion DKK ( $€$ 0.94 billion) with an increase of $19 \%$ from 2013 to 2015. In the same period, the sale of organic food products through catering, canteens and restaurants grew with $69 \%$ to 1.7 billion DKK ( $€ 0.23$ billion). The import of organic food products grew with $34 \%$ to 2.4 billion DKK ( $€ 0.32$ billion), and the export grew with $29 \%$ to approximately 2 billion DKK ( $€ 0.27$ billion) (Danmarks Statistik 2017; Jensen and Pedersen 2015). Denmark is the most intensively farmed country in the EU (Lundsgaard et al. 2016). In 2016 , the agricultural area was approximately 2.65 million hectares corresponding to $61.8 \%$ of the total area, and $88 \%$ of the agricultural area were in rotation with intensive production (DS Nyt 2016). Since 2015, organic farming has experienced a renewed growth after some years of stagnation and even decline. In 2015 conversion checks, free of charge was offered to conventional farmers; in 2016, the area increased with 21.000 ha; and in 2017 , about 40.000 ha is expected to be converted-a growth of $34 \%$ in 2 years to a total area of about 237.000 ha or about $8.9 \%$ of the total agricultural area (Landbrug and Fødevarer 2016). The number of organic farms grew from 2014 to 2015 with $3.1 \%$ to 2636 farms, corresponding to $7.2 \%$ of the total number of farms (NaturErhvervstyrelsen 2016). In 2015, the average area of organic farms was 70.3 ha compared to 71.8 ha for all farms. The $24.3 \%$ of the organic farms with more than 100 ha land farmed $71.6 \%$ of the organic area, whilst the $31.1 \%$ of the organic farms with less than 10 ha farmed only $2.1 \%$ of the organic area. Animal husbandry farms made up $56.8 \%$ of the organic farms. Of the total number of farms, $14.7 \%$ were dairy farms, $18.8 \%$ beef cattle farms, $6.7 \%$ pig farms, $9.9 \%$ sheep farms and $6.7 \%$ poultry farms. The organic production area consisted of $57 \%$ roughage, whole crop and grass and $33 \%$ cereals, oil seed crops and seed legumes, whilst the remaining $10 \%$ consisted of crops for seed production, vegetable and potato production, fruit and wood production and uncultivated areas under special environmental programmes (NaturErhvervstyrelsen 2016; see also Jensen and Pedersen 2015).

Organic farming as a multitool in relation to public goods

In public regulation and policy action plans, the focus is often at one public good at a time, e.g. the Nitrate Directive (Council Directive 91/676/EEC 1991), which aims at protection of the water quality across Europe by preventing pollution of groundwater and surface waters with nitrate from agriculture, hereby contributing to the public good 'Environment'. The directive requests the member states to provide and update action plans for vulnerable areas to reduce nitrate pollution. However, it only sets a specific limit for application of animal manure of $170 \mathrm{~kg}$ nitrogen $(\mathrm{N}) / \mathrm{ha}$, whilst the $\mathrm{N}$ application in other organic and synthetic (=chemical) fertilisers is not regulated. Regulation of pesticide use and protection of biodiversity and animal welfare is developed and implemented separately. As indicated in the EU regulation for organic agriculture and in the industry's own principles, organic farming is perceived having multiple effects on a set of public goods and as such could function as a simple policy tool supporting multiple societal objectives (see also Schader et al. 2014), as shown in Fig. 1.

According to this idea, the organic principles (IFOAM 2005) provide the potential contribution of organic farming to the public goods. The specific legal requirements of the EU Organic Regulation provide a basic (or minimum) contribution of organic production to public goods related to agriculture and food. 
Fig. 1 Organic production perceived as a multitool in relation to the contribution to public goods. Categories refer to chapters in the knowledge synthesis (Jespersen 2015; Jespersen et al. 2015); see further details there

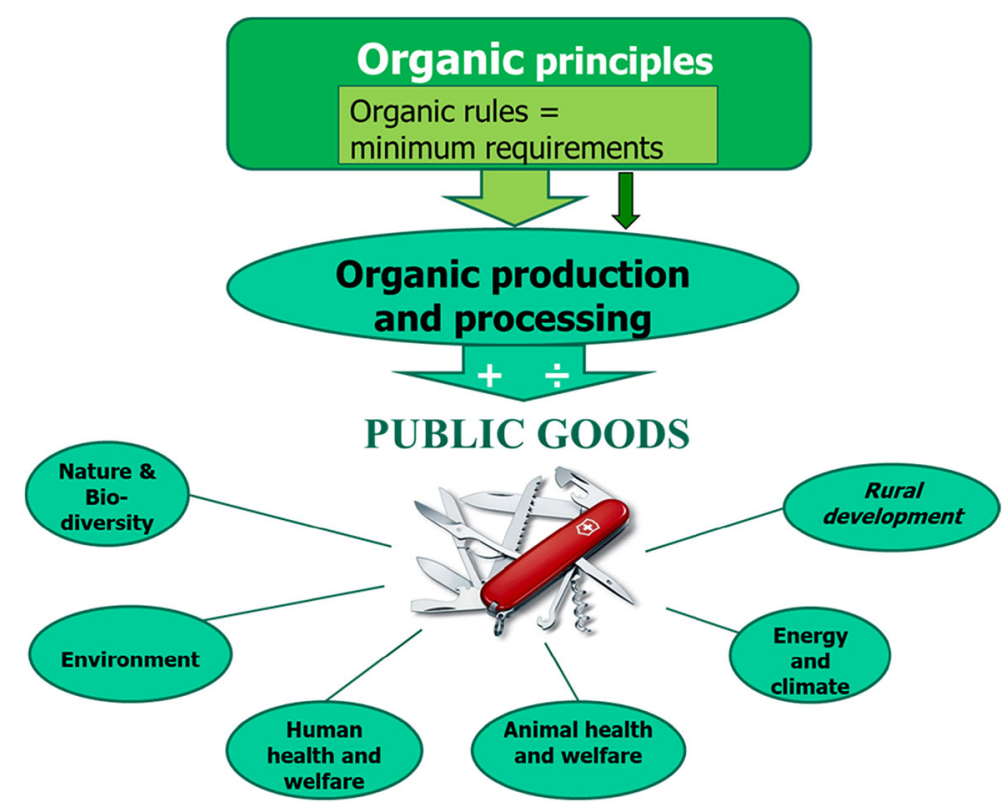

However, the impact of organic farming on different public goods is not just a direct result of the requirements of the EU Organic Regulation. It also depends on other factors, such as the type of farm (arable crops, vegetables, fruit, dairy, beef, pig, poultry, or mixed production, etc.), the size of the farm, the geographical location of the farm and not the least, the management of the farm. Therefore, the actual outcome needs to be assessed in order to improve the regulation and the organic farmers' practices.

Based on this idea, the objectives of this study were

- To analyse to what extent organic farming, as practiced in Denmark, contributes to the selected public goods: 'Nature and Biodiversity', Environment, 'Energy and Climate', 'Human Health and Welfare' and 'Animal Health and Welfare' and

- To identify the synergies and dilemmas of the organic rules in relation to the different public goods.

The specific analysis has focused on the effects of two core requirements of the EU Organic Regulation, which have very high priority for the public authorities as well as for the consumers: the ban on the use of synthetic pesticides in organic crop production and the very restrictive use of antibiotics in organic animal production. Based upon these two examples, the development potential of organic farming in relation to contributing to the public goods was discussed.

\section{Methods}

This study was mainly based on a comprehensive Danish knowledge synthesis, which was carried out in 2015 by a multidisciplinary team of the 70 leading Danish researchers and experts with documented expertise in organic farming and relevant organic farming research as well as in assessment of the effects on the abovementioned public goods (Jespersen 2015; Jespersen et al. 2015). Overall, the synthesis was based on a comprehensive narrative review of relevant scientific literature based on principles described by O'Connor and Sargeant (2015). In the individual chapters of the knowledge synthesis (related to the specific public goods; Fig. 1), the challenges and general legislation and action plans for agriculture in relation to sustaining and/or improving the different public goods were described. Afterwards, the organic principles and specific requirements for organic production relevant for each of the public goods were identified, and the positive, neutral and negative effects in relation to each public good were analysed using existing literature. Thus, the existing international scientific review papers covering different aspects of organic agriculture vis-àvis, e.g. climate, biodiversity, broader environmental aspects, animal welfare and consumer health, formed the core literature for each chapter following the narrative logic of the link between principles, regulation and effects on public goods. Where the existing reviews did 
not always cover sufficiently important aspects, authors supplemented with own systematic reviews of literature on specific topics relevant for the narrative (see reference lists provided at the end of each chapter in Jespersen 2015). Danish research results documented in international peer-reviewed scientific journals, secondly national Danish publications, were given priority, but no relevant literature was omitted at this stage. Based upon these findings, a synthesis across the public goods identified synergies and dilemmas in the contribution and consequences of the organic principles and regulation to the set of public goods. Finally, recommendations were made for further documentation, research, development and communication to improve the contribution of organic farming to the public goods.

In this paper, building on the larger synthesis, we applied a different perspective by taking a starting point in the ban on synthetic pesticides, respectively, the restricted use of antibiotics in order to identify and demonstrate where possible the direct and indirect effects of these core requirements in organic agriculture in relation to selected public goods. With 'indirect' effects, we here refer to the fact that the actual organisation and praxis on organic farms depend on a number of interrelated considerations motivated by the needs to manage with no or low levels of pesticides and medicine. Therefore, requirements for, e.g. crop rotation and outdoor access for livestock, were also part of the analysis of potential impacts on public goods. The public goods and policy relevance of these aspects was argued through a short review of the status of use and the relevant legislation and action plans for control and reduction of the consumption of pesticides and antibiotics in agriculture in general. Finally, we identified important synergies and dilemmas of the organic rules in relation to the different public goods emphasising the needs for further development of organic farming as seen from this perspective.

\section{Results}

Pesticides

Status, legislation and action plans for the use of pesticides in relation to public goods

We use the term 'pesticide' as the common term for herbicides, fungicides, insecticides, acaricides, nematicides, molluscicides, rodenticides, growth regulators and repellents. Most pesticides are chemically synthesised (synthetic), although some are based on naturally occurring compounds. In 2014, the total sale of pesticides in Denmark was 9075 t corresponding to $0.5 \%$ of the total sale of pesticides in the EU-28. The proportion of herbicides and plant growth regulators was considerably higher in Denmark (63\% of total pesticide sale) compared to the EU-28 (33\% of total pesticide sale), whilst the relative sale of fungicides, bactericides and insecticides on the other hand was considerably lower in Denmark than in the EU-28 (27 compared to 44\% of total pesticide sale) (Eurostat 2016). In order to protect consumer and animal health, the EU has introduced maximum residue levels (MRLs) for pesticides in food and feed of plant and animal origin in EU Reg. $396 / 2005$, which also apply to organic food and feed products. This regulation also lays down rules for the official control of MRLs, reporting and sanctions by the Member States, and it amends Council Directive 91/ 414/EEC of 15 July 1991, which is the basic legislation for authorisation of pesticides. According to the pesticide residue control programme of the EU for 2015, the share of organic food samples with pesticide residues was $13.5 \%$, compared to $43.9 \%$ with pesticide residues for the conventional food samples (Table 1; EFSA 2017). The Danish pesticide residue control programme in 2015 found residues in more than $50 \%$ of samples from imported fruits and vegetables, whilst the proportion was lower in Danish products (Table 1). Only one organic sample contained pesticide residues, which the authorities found was most likely due to unintentional contamination from a neighbouring conventional field (Fødevarestyrelsen 2016).

The use of pesticides in the EU in relation to public goods is regulated by Directive 2009/128/EC, establishing a framework for community actions to achieve the sustainable use of pesticides. According to Preamble 5 of this Directive, the Member States should use 'National Action Plans aimed at setting quantitative objectives, targets, measures, timetables and indicators to reduce risks and impacts of pesticide use on human health and the environment and at encouraging the development and introduction of integrated pest management and of alternative approaches or techniques in order to reduce dependency on the use of pesticides'. Danish pesticide action plans implemented since 2004 (Ministerierne for Miljø og Fødevarer 2004) lately aimed at reducing the impact of pesticides on health, nature and environment with $40 \%$ by the end of 2015 
Table 1 Pesticide residue levels above and below maximum residue level (MRL) in conventional and organic food samples analysed under the control programmes in 2015

\begin{tabular}{|c|c|c|c|c|c|c|}
\hline \multirow[t]{2}{*}{2015} & \multicolumn{2}{|c|}{ EU programme (EFSA 2017) ${ }^{\mathrm{a}}$} & \multicolumn{4}{|c|}{ Danish pesticide residue programme (Fødevarestyrelsen 2016) } \\
\hline & Conventional & Organic & Conven & & & Organic \\
\hline Samples & & & Danish & $\mathrm{EU}$ & Third country & Danish \\
\hline Residues < MRL & $43.9 \%$ & $13.5 \% \mathrm{~b}$ & $27.9 \%$ & $57.8 \%$ & $51.4 \%$ & 0 \\
\hline Residues > MRL & $2.8 \%$ & $0.7 \%$ & $0.4 \%$ & $0.8 \%$ & $4.9 \%$ & $0.4^{\mathrm{c}}$ \\
\hline Multiple residues & $28.0 \%$ & $0.06 \%$ & $10.0 \%$ & $29.9 \%$ & $32.5 \%$ & 0 \\
\hline
\end{tabular}

\footnotetext{
${ }^{\mathrm{a}}$ The samples included $25.8 \%$ food samples from third countries

${ }^{\mathrm{b}}$ Thirty-eight percent of these samples contained substances, which most likely were naturally occurring or persistent environmental pollutants or substances allowed in organic farming according to the EU Reg. 889/2008 — in particular copper

${ }^{\mathrm{c}}$ One parsley sample with prosulfocarb, most likely polluted from autumn spraying of neighbouring field
}

compared to 2011 (Miljøministeriet 2012). This was not fully achieved (Miljøstyrelsen 2017). Policy tools for the reduction of pesticides use include restrictive approval of pesticides, pesticide tax, restrictions on the use of pesticides in certain areas (e.g. areas with groundwater interests) and CAP support to avoid the use of pesticides, e.g. by supporting organic farming.

\section{Relevant organic principles and legal requirements}

The principles of organic farming in EU Reg. $834 / 2007$, Articles 4 and 5, state that 'the use of chemically synthesised inputs is restricted to exceptional cases, where other methods or inputs are not available. Instead, the maintenance of plant health should be based on preventive measures, such as the choice of appropriate species and varieties resistant to pests and diseases, appropriate crop rotations, mechanical and physical methods and the protection of natural enemies of pests'. Thus, pest management in organic farms should be based on preventive measures and use of agroecological practices (Wezel et al. 2009). The few active pesticide substances of natural origin that are allowed in organic farming in cases where other measures are not sufficient are listed in Annex II of EU Reg. 889/2008.

\section{Potential contribution of organic farming to public goods due to very restrictive use of pesticides}

In Denmark, 156 active substances are approved for plant protection in conventional agriculture, whilst 492 active substances are allowed in the EU (DG Sanco
2017). Besides, basic substances that are covered by the definition of 'foodstuff' in EU Reg. 178/2002, only 23 active substances are allowed in organic farming, of which some may only be used for very restricted purposes and some only in traps in orchards (EU Reg. 889/2008 amended version, Annex II). In Denmark, only 22 active substances are allowed as there is a general ban on the use of copper fungicides in Denmark since 1995. Plant growth regulators and herbicides are not allowed in organic agriculture. Instead, weed control ideally is based on a balanced crop rotation, which often includes legumes and/or clover grass and in combination with mechanical or other physical weed control. Diseases and insect pests in organic farming may also be controlled by crop rotation, companion planting, robust and resistant crop varieties and promotion of beneficial insects (predators) by functional biodiversity initiatives such as hedgerows, insect hotels and flower stripes in the field. The direct consequences of the restrictive use of pesticides and the indirect effects of the implementation of agroecological practices on different public goods are analysed in more detail in the following.

\section{Influence on nature and biodiversity}

Comparative studies have documented that organic farming potentially increases biodiversity in fields and adjacent habitats with $30 \%$ relative to conventional farms (Bengtsson et al. 2005; Hole et al. 2005). In a comprehensive meta-analysis, Tuck et al. (2014) has confirmed that the $30 \%$ increase is a robust result, which has been valid for 30 years, and that the increase in the number of species on organic farms especially depends 
on how intensively the farming area is managed, measured as the number of fields in rotation of the total area. The more intensively the whole area is managed, the greater positive effect of organic farms, and the effect is greatest on wild plants and pollinating insects. However, Birkhofer et al. (2014) found the greatest effect of organic farming on birds, beetles and butterflies, which shows the difficulties in getting an unambiguous/precise picture of the effects. The number and diversity of natural enemies of pest animals, including spiders, parasitic wasps and ground beetles, is also higher in organic fields (Crowder et al. 2010). The documented beneficial effects can be directly related to the absence of pesticides, but also to the utilisation of organic manure and a different crop composition on organic farms (Andersen et al. 2014; Boutin et al. 2014). Additionally, the requirement that organic cattle must have access to daily grazing in the summer period also affects the biodiversity of certain groups of organisms positively. The few non-synthetic insecticides and fungicides that are allowed in organic production are only used sparingly in fruit orchards and vegetable production and not in agricultural crops, so direct as well as indirect effects of pesticides are normally absent in organic agriculture, though contamination from spraying of neighbouring conventional fields may take place.

As described above, Danish organic farms generally have a more varied crop composition in the rotation than conventional farms with more legumes and clover grass. Flowering legumes are attractive food sources for pollinators (Hanley et al. 2011; Knight et al. 2009). Besides, organic farms have more perennial grass fields with low yield and higher diversity of wild plants than conventional farms (Aude et al. 2003; Henriksen 2013; Petersen et al. 2006). This is a response not only to restrictive pesticide use but also other organic regulation such as limited fertiliser use and requirements for grazing of all livestock, as discussed below. The absence of pesticides, the crop composition, the share of perennial crops, the soil tillage and crop residues all have great influence on the diversity of soil organisms (Vályi et al. 2014). Surface dwelling earthworms and soil microarthropodes are negatively influenced in number and species diversity by mechanical soil cultivation, especially ploughing (Crittenden et al. 2015; Ernst and Emmerling 2009; Peigné et al. 2009). Tests in other countries have shown that ploughing reduces the biodiversity of arbuscular mycorrhiza in the soil (Köhl et al.
2014; Säle et al. 2015), and the fields in rotation are generally ploughed more in organic than in conventional agriculture. However, research has shown that the diversity of microorganisms is higher in soils with organic compared to conventional production (Oehl et al. 2004; Stagnari et al. 2014), so other factors may have greater influence on the soil biodiversity than ploughing.

Moreover, the use - or not - of herbicides affects the biodiversity of the uncultivated habitats close to the fields negatively. Analyses of the flora in Danish windbreaks between fields have shown that there are much more dicotyledon plant species in the bottom of the windbreaks on organic farms than on conventional, independently of soil type and age of the windbreak (Boutin et al. 2014; Bruus et al. 2008). These and other studies (Petersen et al. 2006) have also shown that recolonisation of the windbreaks with the complete flora by conversion to organic farming may take very long time (up to more than 30 years), whilst the recolonisation of the field areas is much faster. Finally, however, the contribution of organic agriculture to biodiversity preservation is questioned by some biologists claiming that this production form does not in itself protect the specific red-listed species; many of which depend on uncultivated land (Ejrnæs 2017).

\section{Influence on environment}

Besides biodiversity preservation, the main agrienvironmental challenges and focus areas in Denmark are the impact from nitrogen and pesticides on groundwater, nitrogen and phosphorous eutrophication of freshwater and marine water and the maintenance of soil resources and quality. Non-use of pesticides potentially has direct and indirect effects on all aspects. In Denmark, almost all drinking water is tapped from the groundwater, for which reason there is focus on the risk of pesticide and nitrate contamination. Based on the EU Drinking Water Directive (Council Directive 98/83/EC, 1998), the limit value for pesticides and degradation products thereof in groundwater and drinking water in Denmark is set at $0.1 \mu \mathrm{g} / \mathrm{l}$ for each compound and at $0.5 \mu \mathrm{g} / 1$ for the sum of compounds (Miljø- og Fødevareministeriet 2016b). In 2014, pesticides were found in $26 \%$ of the water drillings of common waterworks (minimum 10 households) and the threshold limit value was exceeded in $3.6 \%$ of the water drillings selected for testing (Miljøstyrelsen 2016). However, the 
findings mainly concerned pesticides or degradation products thereof that are no longer allowed in Denmark. Because of the ban on the use of synthetic pesticides, organic agriculture has been proposed as a means to protect drinking water resources in areas that are characterised as particularly vulnerable to pesticide leaching (Naturstyrelsen 2015). Besides leaching, pesticides may be lost by air drifting during the process of application. A Danish study showed that the pesticide concentration in streams near agricultural land often exceeds the limits for growth of algae and daphnia and thus impacts the entire microflora and microfauna (Rasmussen et al. 2015). This is supported by an EUwide study (Malaj et al. 2014).

The ban on pesticide use increases the need for mechanical weeding resulting in bare soil in certain periods of the year. This, in combination with the fact that $\mathrm{N}$ fertilisation is based on organic sources like manure and $\mathrm{N}$-fixing legumes, where nitrification takes place in periods with no crop uptake of $\mathrm{N}$, increases the risks of nitrate leaching. Under Danish conditions, the nitrate leaching from the root zone in organic cash crop rotations are on level with conventional, despite of a lower overall application of nitrogen to the organic crops (Knudsen et al. 2014).

\section{Influence on energy use and climate change}

There are no specific requirements in the EU Organic Regulation nor the Danish guidelines on organic farming regarding energy consumption or climate change mitigation except for general objectives of EU Reg. $834 / 2007$, Article 3, stating that 'organic farming shall make responsible use of energy and natural resources'. The very restricted use of pesticides in organic farming induces a change in the whole cropping system to more varied crop rotations with more legumes and clover grass for nitrogen fixation and application of mechanical and thermal weeding methods. This, together with the ban on chemical fertilisers, gives rise to changes in energy consumption and emissions of greenhouse gasses compared to similar conventional plant production systems.

Comparisons of energy consumption per ha for organic vs. conventional crops generally show lower energy use in organic farming, especially because of the non-use of chemical fertilisers, which normally is attributed an indirect energy 'cost' in MJ per kg N. This energy cost often amounts to levels comparable with the direct energy cost from diesel use for the field operations (approximately 100-140 MJ per ha under Danish conditions). The diesel use is either similar in the two systems for the same crops or sometimes higher in organic agriculture due to manure handling (Halberg et al. 2008b; Halberg 2012), whilst the extra diesel use from mechanical weeding replacing pesticides in most cases is of minor importance when comparing systems. However, there is an indirect energy cost, which may be attributed to the $\mathrm{N}$ content in manure imported to organic farms, in a situation where the manure $\mathrm{N}$ could have replaced $\mathrm{N}$ in chemical fertiliser on a conventional cash crop farm (Halberg et al. 2008b; Knudsen et al. 2011). This indirect energy cost in MJ per $\mathrm{kg} \mathrm{N}$ is normally not included in the comparisons of organic and conventional farms. When comparing energy use per kg crop produced, the higher conventional yields - which again are due to the combined use of pesticides and fertiliser-partly compensate for the higher-energy input, and therefore, the relative energy use per kg cash crop is only marginally lower in organic systems (Halberg et al. 2008b). In fact, organic crops with very low yields compared with conventional, such as potatoes, have higher energy costs per $\mathrm{kg}$ crop compared with conventional (Halberg 2012).

In 2014, the Danish agricultural sector contributed with $20 \%$ of the overall greenhouse gas (GHG) emission in $\mathrm{CO}_{2}$ equivalents, and next to the energy sector, it is the largest source of GHG emission in Denmark. The emission of GHG in organic crop production is generally lower per ha in organic farming than in conventional farming but not always lower per produced unit due to lower yields in organic crops (Knudsen et al. 2011). Knudsen et al. (2014) calculated the GHG emission for organic and conventional crop production based on a dry matter production of $4100 \mathrm{~kg} \mathrm{DM} / \mathrm{ha}$ in organic farming compared to $5750 \mathrm{~kg} \mathrm{DM} / \mathrm{ha}$ in conventional production in longterm crop rotation experiments. The GHG emission for organic crop production was $0.440 \mathrm{~kg} \mathrm{CO}$ equivalents/kg DM and $1757 \mathrm{~kg} \mathrm{CO}$ equivalents/ha compared to $0.425 \mathrm{~kg} \mathrm{CO}$ equivalents $/ \mathrm{kg} \mathrm{DM}$ and $2396 \mathrm{~kg} \mathrm{CO}$ equivalents/ha in conventional production. However, across a large number of studies, GHG emission per produced unit is comparable between organic and conventional crops with some studies showing higher emission in conventional crops and others the reverse (Mondelaers et al. 2009; Knudsen 2011; Tuomisto et al. 2012; Meier et al. 2015). 


\section{Influence on human health and welfare}

The direct effect of the ban of synthetic pesticides in organic farming is a much lower frequency of detected pesticide residues in organic food samples compared to conventional (see Table 1), which means a lower exposure to pesticides for consumers of organic food. In addition, the very restricted use of pesticides also reduces the occupational exposure of farm workers to pesticides. Several studies on the negative effects of pesticides on human health are related to occupational exposure (Mie and Wivstad 2015), whereas only few look into the effect from exposure to pesticidecontaminated food. A main motivation for consumers buying organic food products is belief in positive health attributes especially due to avoidance of pesticides and medicine residues in the food (Christensen et al. 2014; Denver and Christensen 2010). However, it is not possible to give clear scientific evidence that organic diets generally improve human health, because the biological and sociological interactions are too complex. Negative effects on children's cognitive development from organophosphate pesticides have been presented in a recent report from European Parliamentary Research Service (EPRS), where organic food was suggested as a way to minimise exposure, in particular during pregnancy and infancy (STOA 2016). In these studies, it was metabolites that were measured and the uncertainties using these metabolites were not discussed in the report, e.g. that the metabolites also can originate from other substances than pesticides. Chiu et al. (2015) investigated the relation between quality of semen and intake of fruits and vegetables and found a correlation between low semen quality and fruits and vegetables with high levels of pesticides. Contrary to that, they found a positive correlation between semen quality and intake of fruits and vegetables with low or moderate levels of pesticides, and the authors concluded that more data are needed before final conclusions can be made. Generally, toxicological studies are performed on effects of single pesticides and focusing on high contamination levels above the defined MRL. In relation to assessment of a reduced human health risk related to organic food compared to conventional food, it is necessary to assess the risk of pesticide intake below MRL and also to include the cumulative risk related to simultaneous intake of several types of pesticides (cocktail effects) (Hass et al. 2012). Consumption of organic food will minimise the pesticide exposure of organic consumers and may have a positive health impact, though the exact effects are difficult to assess.

Some crops, especially cereals, may be contaminated with mycotoxins, i.e. toxins produced by certain fungi, which amongst other things may cause cancer or endocrine disruption. The risk of finding mycotoxins in organic cereal grains and flour products might be expected to be elevated compared to conventional grains and flour products, because of the non-use of synthetic fungicides in organic agriculture. However, the greatest risk for formation of mycotoxins is connected to the humidity of the grains during harvest, drying and storage, and analyses by the Danish Veterinary and Food Administration have shown that there is no difference in the content of mycotoxins between conventional and organic grain and flour products (Petersen et al. 2013). Studies on oats, barley and wheat in Norway, Poland and the UK confirm these findings, and for some toxins, organic grains had lower content of mycotoxins than conventional (Bernhoft et al. 2010; Blajet-Kosicka et al. 2014; Edwards 2009a, b).

\section{Influence on animal health and welfare}

During the period of 2007-2014, the Danish Veterinary and Food Administration analysed 2803 samples of feedstuffs and found pesticide residues in $22 \%$ of the samples, of which $66 \%$ contained one pesticide, whilst the remaining $34 \%$ contained between 2 and 15 different pesticides. In total, 69 different pesticides were found and the pesticide residues were mainly found in feed grains and their by-products, soya bean meal, soya bean hulls and citrus pulp, but in concentrations below the EU limit values for pesticide residues in food products (Fødevarestyrelsen 2015a). The pesticides most often found in the pesticide-contaminated samples were glyphosate and chlormequat (42\%, respectively; $30 \%$ of the contaminated samples). Therefore, animals consuming conventional plant feed products will most often ingest pesticide residues in the feed. In the Danish 2017-2021 Pesticide Strategy, the spraying of crops with glyphosate later than 30 days before harvest is prohibited in crops for human consumption but this restriction does not apply to crops for animal feed (Anonymous 2017).

The influence of pesticides on animal health and welfare is sparsely documented except for honeybees, which are particularly sensitive to some insecticides. Pesticides are in fact a key factor for explaining 
honeybee declines; others are pathogens and parasites and lack of suitable feed resources. Sub-lethal amounts of neonicotinoids can cause impaired communication and disorientation and affect the winterisation of healthy colonies, subsequently leading to colony collapse disorder (CCD) (Lu et al. 2014). Most animal feeding studies have been performed as models for human health aspects, but they have generally been aimed at comparing the difference between organic and conventional feeding and not focused on differences in the content of pesticide residues. This has been considered in a two-generation rat study using four experimental feeds produced under controlled conditions using organic (manure) vs. mineral fertiliser and organic vs. conventional plant protection. The study showed no main effects of the differences in crop protection, but a range of significant interactions between differences in fertilisation and crop protection occurred (Srednicka-Tober et al. 2013). Denmark, like other European countries, imports large amounts of protein feed from outside Europe in the form of soya bean products, which are mainly from glyphosate (roundup) resistant genetically modified (GM) soya plants. About $80 \%$ of the soya bean meal are used in pig feed, whilst the rest are used for cattle and broilers (Bosselmann and Gylling 2014). Glyphosate is not only a herbicide but also patented as a remedy against parasites, bacteria and other microorganisms. Thus, beneficial bacteria in the gut of animals may be affected by glyphosate that enters the digestive system via the diet, whilst other potentially pathogenic bacteria such as Salmonella sp. and Escherichia coli are less sensitive to glyphosate (Myers et al. 2016; Sørensen et al. 2014). Glyphosate also binds to a wide range of metals, which may lead to deficiencies of trace minerals and result in problems for animals in particularly sensitive phases (weaning, early pregnancy, birth, etc.), where the minerals are essential for several vital body functions. However, until now, too few feeding studies have been carried out with GM soya containing glyphosate residues vs. glyphosate-free non-GM soya in relation to their influence on the gut microbiota and micromineral status of farm animals to draw any conclusions (Sørensen et al. 2014). In the feed of organic animals, it is forbidden to use products of GM plants, but it is allowed as a derogation until the end of 2017 to use up to $5 \%$ non-GMO conventional protein feed to monogastric organic animals (EU Reg. 889/2008 amended version). Thus, the risk of finding negative impact of glyphosate residues on the health of organic animals is lower than for conventional animals.

\section{Overview of direct and indirectly derived effects of restricted use of pesticides}

In summary, the ban on synthetic pesticides has a number of direct positive effects on different public goods, i.e. on Environment (no pesticides in groundwater and surface water), Nature and Biodiversity (more diverse flora and fauna on and around the farm) and Human and Animal Health and Welfare (pesticide-free food and feed products and no exposure of farm workers to pesticides). Figure 2 presents an overview of the systemic effects of using agro-ecological practices as a response to the non-use of pesticides - and the linked reduced fertiliser use - in organic agriculture.

Besides, there are a number of indirect positive effects on the public goods due to the cropping methods implemented to compensate for the non-use of pesticides, i.e. diversified crop rotation including legumes and perennial clover grass, lower $\mathrm{N}$ supply in organic fertilisers, mechanical weeding and protection of natural enemies of pests. Their effects are also positive in relation to several public goods, except for mechanical weeding, which has negative influence on the environment due to increased risk of nitrate leaching and on biodiversity because of disturbance of the microflora and macroflora and fauna. The effect of the ban on synthetic pesticides combined with lower $\mathrm{N}$ supply also has a negative effect on the yields in organic farming compared to conventional and hereby on climate change per unit produced, but the opposite is the case per area unit.

\section{Antibiotics}

Status, legislation and action plans for the use of antibiotics in relation to public goods

Antibiotics are used for treatment or prevention of bacterial infections. They are produced by certain microorganisms (fungi or bacteria/actinomycetes) or they may be of synthetic origin. Antimicrobial resistance (AMR) is the ability of microorganisms to resist antimicrobial treatments, especially antibiotics. Excessive and inappropriate use of antimicrobial medicines for humans and animals and poor infection control practices has transformed AMR into a serious threat to public health 


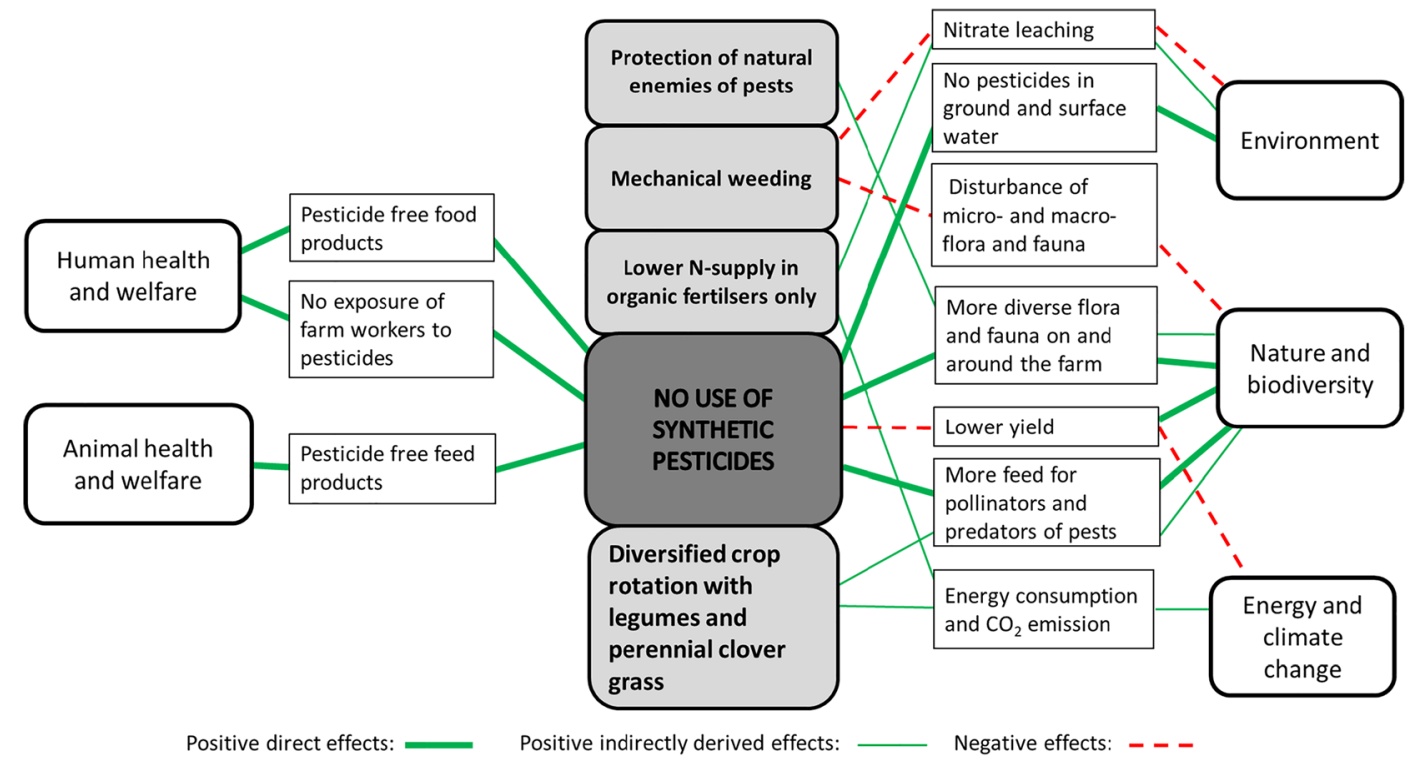

Fig. 2 Direct and indirect contribution of organic farming to public goods due to ban of synthetic pesticides plus compensating cropping methods

worldwide. This has triggered increasing health care costs, prolonged hospital stays, treatment failures and a significant number of deaths and an annual cost of approximately $€ 1.5$ billion for health care and productivity losses in the EU. Infections by multidrug-resistant bacteria are estimated to cause about 25,000 deaths in the EU every year (EMA 2017). In Denmark, the number of persons infected annually with methicillin-resistant Staphylococcus aureus (MRSA) has tripled from 2010 to 2015 , where $40 \%$ of the 2973 infections were transmitted from animals (Statens Seruminstitut 2017).

The sales of antibiotics to animal producing farms is expressed by means of a Population Correction Unit (PCU). This is applied as a proxy for the size of the food-producing animal population and used for expression of the sales in milligrammes of active ingredient sold per PCU. According to the European Medicine Agency (EMA), the largest amounts of veterinary antibiotic agents sold in 29 European countries in 2014 in $\mathrm{mg} / \mathrm{PCU}$ were tetracyclines $(33.4 \%)$, penicillins $(25.5 \%)$ and sulphonamides (11\%) (EMA 2016). There was a large difference in the sales between countries in the range from $3.1 \mathrm{mg} / \mathrm{PCU}$ (Norway) to $418.8 \mathrm{mg} / \mathrm{PCU}$ (Spain). In Denmark, the sale was $44.2 \mathrm{mg} / \mathrm{PCU}$, and the major part was used for pigs, followed by cattle and poultry. There has been a slight reduction of $2.4 \%$ in the amount sold in the EU in the period of 2011-2014. Ten countries including Denmark lowered their sale (in mg/
PCU) with more than 5\%, whilst there was an increase of more than $5 \%$ in five countries during the 5 -year period (EMA 2016).

Concerns about development of antimicrobial resistance and transfer of antibiotic resistance genes from animal to human microbiota led to withdrawal of antibiotics as growth promotors in animal feeds in the EU from 1 January 2006, after which date antibiotics are only allowed for veterinary purposes. In the Danish antibiotic resistance surveillance and control programmes, Salmonella sp. was found in $1.3 \%$ of the samples from pig caeca (803 pig samples) and pig carcass swabs $(15,905$ pork samples) in 2015. Of the isolates from pigs, $49 \%$ contained Salmonella sp. resistant to at least one antimicrobial agent, whilst this was the case for $50 \%$ of the isolates from pork. Campylobacter sp., which is the most commonly reported cause of gastrointestinal bacterial infections in humans in Denmark as well as in the EU, was found in $29 \%$ of the samples from broilers and domestically produced broiler meat (286 samples in total), of which 32 and $26 \%$, respectively, were resistant to at least one antimicrobial agent (DANMAP 2015). In 2014, a Danish screening for MRSA, four out of 64 organic pig herds $(6 \%)$ were tested MRSA positive compared with $68 \%$ of the conventional pig farms (Fødevarestyrelsen 2015b).

In 2011, the European Commission passed its first Action Plan against the rising threats from antimicrobial 
resistance (COM 2011), and in 2017, the commission will launch a second Action Plan including securing EU funds and instruments in order to promote innovation and research against AMR through National Action Plans. According to an opinion paper prepared jointly by EMA and the European Food Safety Agency (EFSA) for the European Commission, measures to reduce antimicrobial use and AMR in animal husbandry should focus on the principles of 'reduce, replace and rethink' (EMA and EFSA 2017). Of these, the following recommendation is particularly interesting in relation to organic farming and its potential role as model: 'rethinking the livestock system by implementing farming practices that prevent the introduction and spread of disease'.

In 2014, the Danish cattle industry set a target for antibiotic use of $20 \%$ reduction for the period of 2010 2018, and in 2015, the Danish pig industry set a $10 \%$ reduction target for the period of 2015-2020 (DANMAP 2015). These initiatives were followed by adoption of a 4-year National Action Plan for control of MRSA in farm animals in 2015 (Anonymous 2015), according to which the following initiatives were to be implemented: a $15 \%$ reduction of the consumption of antibiotics in pig production from 2015 to 2018, improved hygiene for staff working in pig stables, reduction of infection transmission in the individual farms, program for surveillance of the development of animal AMR/MRSA and strengthening of research in transmission routes for animal MRSA and international initiatives - including putting pressure to promote the antibiotic strategy of the EU.

\section{Relevant organic principles and legal requirements}

According to Council Regulation (EC) 834/2007, Article 5 , the main principles for organic animal production in the EU is that 'Animal health shall be maintained by encouraging the natural immunological defence of the animal, as well as the selection of appropriate breeds and husbandry practices'. This means that 'animal husbandry practices shall be applied, which enhance the immune system and strengthen the natural defence against diseases, in particular including regular exercise and access to open air areas and pastureland where appropriate'.

A number of specific requirements to organic livestock farmers are related to the prevention of needs for medication such as Articles 19-22 (in EU Reg. 834/2007), which specify longer weaning periods for organic animals compared to conventional, maximum use of grazing pasture, daily feeding of roughage to all animals and minimum $60 \%$ roughage for herbivores. Likewise, Halberg et al. (2008a, b) specify that the livestock shall have permanent access to open air areas when conditions and weather permit this and that 'stocking densities and housing conditions shall ensure that the developmental, physiological and ethological needs of animals are met'. Thus, the space requirements per animal are considerably larger for organic compared with conventional animals, and other conditions, e.g. light, daily access to roughage, weaning age and other factors that are important for animal health and welfare, are also stricter.

Other articles deal with disease prevention and specify that preventive treatment with allopathic veterinary medicine including antibiotics is forbidden, except for vaccination of animals. Moreover, growth promotors and synthetic amino acids cannot be used. On the other hand, the regulation stress that when ill, livestock should in fact be treated immediately to avoid their unnecessary suffering, and 'chemically synthesised allopathic veterinary medicinal products including antibiotics may be used where necessary and under strict conditions when the use of phytotherapeutic, homoeopathic and other products is inappropriate' (Article 14). As a precautionary measure, the withdrawal period for animals treated with chemically synthesised allopathic medicine including antibiotics is twice the legal withdrawal period for conventional animals. Animals, which have been treated with allopathic medicine including antibiotics more than three times within 12 months, or more than once, if their productive life cycle is shorter, may not be sold as organic, neither live nor as food products.

\section{Contribution of organic farming to public goods due to very restrictive use of antibiotics}

In general, the design and management of organic livestock systems reflect the emphasis on prevention of diseases and promotion of the health of organic animals by good housing standards including hygiene, feeding according to the needs of the animal species and age groups with daily provision of roughage for all species, later weaning plus outdoor access and grazing when the weather permits. The health-promoting measures and management practices applied to reduce or avoid the need for antibiotic treatment of organic farm animals are analysed in relation to each of the public goods in more detail below: 


\section{Influence on nature and biodiversity}

Antibiotic residues from treated livestock are often present in their manure and hereby transferred to the soil where the residues may influence biodiversity through selective effects on microbiota and insects. The presence of antibiotic resistant microorganisms in the soil may be a consequence of certain antibiotics in the manure applied to the soil (Graham et al. 2016; Jechalke et al. 2014). Jechalke et al. (2014) reviewed a number of studies, demonstrating that antibiotics entering into agricultural soil via manure can affect the soil microbial community - and in particular the abundance, diversity and transferability of resistance genes in the short term. Ollivier et al. (2013) found that application of manure from sulfadiazine-treated pigs affected the abundance and diversity of nitrifying microbes in the soil, and led to a decrease in ammonia-oxidising bacteria and an increase of ammonia-oxidising archaea.

The results are varied however; negative (Bartiková et al. 2016) as well as no effects (Baguer et al. 2000) have been reported for environmentally relevant antibiotic concentrations, and it has been argued that focus on effects on non-target microorganisms is needed (Brandt et al. 2015). Recent studies have shown that antibiotics may significantly affect the microbiota in dung and dung beetles negatively (Hammer et al. 2017). In Denmark, more than half $(57.1 \%)$ of the dung beetles are listed on the Danish Redlist (Department of Bioscience 2017), and one of the reasons for this may be the extensive use of antibiotics for livestock. Therefore, soil biodiversity may benefit from the very restrictive use of antibiotics in organic farming.

Until now, only a few studies have considered the effects on non-target organisms of antibiotic resistant bacteria in manure from medically treated animals. The presence of manure borne AMR microbes diminish relatively soon after the application is stopped. Marti et al. (2014) found in a field study with plots cropped with vegetables and fertilised with pig or dairy manure that under conditions characteristic of agriculture in a humid continental climate, a 1-year period following a commercial application of raw manure is sufficient to ensure that an additional soil burden of antibiotic resistance genes approaches background. They therefore recommended pre-treatment by, e.g. composting of the manure before application. Antibiotics and AMR genes occur naturally in soil as almost $50 \%$ of Actinomycetes isolated from soil are capable of synthesising antibiotics for competition reasons, which provide a natural content of antibiotic residues in the soil (Popowska et al. 2012). The use of antibiotics as feed additives for growth promotion in conventional husbandry was prohibited from 2006, but copper $(\mathrm{Cu})$ and zinc $(\mathrm{Zn})$ are still used as feed additives in high amounts. In some cases, they may exert a stronger environmental selection pressure for resistance to antibiotics of the soil microbiota than the specific antibiotic itself (Song et al. 2017).

\section{Influence on environment}

Besides the mentioned effects on biodiversity in and above soils, the main environmental consequences of organic livestock production are ammonia loss and risks of eutrophication due to the wider requirements for feeding and housing livestock, which are linked to the focus on antibiotic prevention. The requirements for outdoor access, roughage and organic feed together with avoidance of synthetic amino acids lead to higher feed use per produced $\mathrm{kg}$ pig and chicken meat and higher protein $\mathrm{N}$ content per $\mathrm{kg}$ feed (Halberg et al. 2010; Larsen et al. 2000; Olsson et al. 2014). This leads to higher risks of losing nitrogen through ammonia volatilisation and leaching especially from manure droppings on concrete outdoor runs, respectively, in the fields where sows roam. Moreover, the larger space requirement and floor design indoors may also lead to a higher ammonia emission, and according to Olsson et al. (2014), higher ammonia emission is typically seen in organic pig and poultry production compared to conventional production.

There is a higher $\mathrm{N}$ leaching from organic pig production compared with conventional per ha and per $\mathrm{kg}$ pig produced (Halberg et al. 2010; Larsen et al. 2000) mainly caused by the high manure $\mathrm{N}$ load on fields with outdoor sows, especially from feeding and soiling spots (Eriksen 2001) resulting in low $\mathrm{N}$ use efficiency in the following crops.

In organic egg production, there is a requirement for outdoor runs (e.g. $4 \mathrm{~m}^{2}$ per hen in EU, $8 \mathrm{~m}^{2}$ per hen in Denmark) but no requirements for removing the nutrients from hen droppings through harvesting of crops in intermediate periods. This creates a risk of nitrate leaching from the outdoor runs (Hegelund et al. 2005), which needs to be reduced by planting and harvesting certain crops such as willow which may provide shelter for hens and be used for bioenergy purposes (Steenfeldt 2015). 
In dairy production, analysis of nutrient balances on farms in combination with nitrate leaching measurements have established that under Danish conditions with a maximum of 1.4 livestock units per ha in organic dairy farms, the leaching is considerably lower (30$40 \mathrm{~kg} \mathrm{~N}$ less per ha) compared to conventional dairy farms (Kristensen and Hermansen 2008; Nielsen and Kristensen 2005).

\section{Influence on energy use and climate change}

The restricted use of antibiotics in organic animal husbandry indirectly influences the use of energy and emissions of greenhouse gasses in organic compared to conventional livestock production due to the mentioned management requirements aiming at improving health and welfare in order to avoid treatments. Thus, the differences between farming systems are mainly caused by the same factors as related to nutrient management (see section on Environment), especially the increased feed use in organic livestock production.

The emission of the GHG nitrous oxide $\left(\mathrm{N}_{2} \mathrm{O}\right)$ and methane $\left(\mathrm{CH}_{4}\right)$ is mainly related to livestock production, which in Denmark is dominated by cattle and pigs (DCE 2016). GHG emission per kg livestock product was almost identical in organic and conventional systems for pig meat (Halberg et al. 2010) and milk (Halberg 2012; Kristensen et al. 2011). Knudsen (2011) in a review found that GHG emission from organic milk production was 10-20\% lower in six of ten comparative studies. However, the variation between farms is high, and Kristensen et al. (2011) found that variation in feed use efficiency caused some organic farms to have higher GHG emissions than most conventional whilst others had lower. There are methodological difficulties in accounting for (differences in) the soil carbon sequestration in such comparisons, but modelling studies suggest that inclusion of this factor would decrease the net GHG emissions more per $\mathrm{kg}$ pork or milk produced in organic than in conventional systems (Halberg et al. 2010). In Danish experiments, conventional grass fields and organic clover grass fields have been estimated to sequester about $1000 \mathrm{~kg}$ carbon (C)/ha annually (Christensen et al. 2009; Schjønning et al. 2012). Because of the larger share of clover grass fields in organic crop rotations, the carbon sequestration is probably in average higher in organic agriculture than in conventional.
Influence on human health and welfare

Antimicrobial resistance is recognised as an important threat to human health. The mentioned regulation of antibiotics use in organic farming and restrictions on marketing of products after medication considerably reduce the risk of finding antibiotic residues in organic animal products delivered to dairies and slaughterhouses. Because the use of antibiotics in organic animal production is low compared to conventional production (Wingstrand et al. 2010; see also next section), there is a lower occurrence of antimicrobial resistance in bacteria isolated from organic production animals (Rosenquist et al. 2009). Low use of antibiotics also provides less risk of mistakes in the production chain, e.g. incorrect delivery of milk to the dairy from antibiotic-treated cows or slaughter of pigs with antibiotic residues. In relation to risks or health benefits for the consumer, it is important that the improved quality is maintained throughout the production chain. Unfortunately, a European study of organic pork production from several countries (France, Sweden and Denmark) showed that the significant differences in the level of antimicrobial resistance observed at herd level (Österberg et al. 2016) seemed to disappear after slaughter and handling of the meat (Jensen and Aabo 2014). This negative change implies cross contamination and may be handled through improved hygiene and management, although the mechanism behind this observation is not yet clear.

As an indirect effect, the requirements for feeding and access to grazing for organic livestock result in differences in the composition of fatty acids in organic milk and eggs compared with conventional. The proportion of healthier fatty acids is more favourable to humans in organic eggs and milk compared to conventional (Anderson 2011; Larsen et al. 2014; Shapira 2010; Schwendel et al. 2015), although studies demonstrating the actual effect on human health are lacking.

\section{Influence on animal health and welfare}

The use of antibiotics and the antibiotic resistance is significantly lower in organic pig production compared to conventional (Wingstrand et al. 2010). The reduced use of antibiotics in organic pig production could be due to differences in treatment thresholds in the two production systems, and the lower application of antibiotics in organic pig production could indicate a welfare problem if diseased animals are not treated or treated too late. 
However, the mortality rate for sows and slaughter pigs in Denmark is not higher in organic than in conventional production (Sørensen 2015). The level of lesions found at meat inspection is higher for some lesions in organic production than in conventional indoor production (Kongsted and Sørensen 2017), but this does not seem to be linked with under-treatment because the level of lesions in conventional outdoor pig production, having the same antibiotic treatment regime as in conventional indoor pig production, is similar to organic pig production. The difference in the level of lesions therefore seems more related to differences in the production system than to differences in the veterinary treatment regime. The piglet mortality rate is higher in organic than in conventional pig farms, which is linked with the requirements for outdoor rearing (Sørensen and Pedersen 2013).

The consumption of antibiotics in the production of $1 \mathrm{~kg}$ of organic milk is only about two thirds of the consumption for the production of $1 \mathrm{~kg}$ conventional milk (Bennedsgaard et al. 2010). Research has shown that a determined effort in Danish organic dairy herds can reduce the use of antibiotics even further (Bennedsgaard et al. 2010; Ivemeyer et al. 2011). In a recent review, Arnott et al. (2017) concluded that pasture-based systems, such as organic milk production in general, provide better animal welfare to dairy cows than indoor-based systems. They found lower levels of lameness, hoof pathologies, hock lesions and mastitis in organic dairy cows than in conventional, which evidently would explain the lower medicine use. Pasture-based systems therefore seem to reduce the need for antibiotic treatments. The lower antibiotic use did not increase the mortality rate of calves which was between 7 and $8 \%$ in organic and conventional dairy herds in 2016 (Raundal et al. 2017). In a Danish study comparing 15 organic and conventional dairy herds, Reiten (2014), however, found a higher level of diarrhoea but a lower level of respiratory diseases in organic calves compared to conventional calves of $0-6$ months.

Previous studies have shown that many organic farmers emphasise active care treatment (Vaarst et al. 2003). Focus on animal care, such as assigning hospital pens with extra bedding and extra milking, promote the welfare of diseased animals. The veterinarian's experience with the herd-specific conditions on organic livestock farms with very restrictive use of antibiotics is important for the prevention and control of diseases. However, often, the veterinarians do not have sufficient experience in facilitating health management on organic livestock farms with a low use of antibiotics (Duval et al. 2016). The duration of antibiotic treatment in organic cattle herds is shorter than in conventional cattle herds. It may be because all medical treatments in Danish organic animal production must be administered by a veterinarian, and therefore, it is more expensive than in conventional animal production, where the farmer is allowed to administer the follow-up treatment himself on the condition that he has a health advisory agreement with a veterinarian. Bennedsgaard et al. (2010) showed that mastitis was treated on average three times in conventional herds where the farmer had a health advisory agreement, whilst in organic herds and herds without a health advisory agreement, the antibiotic treatment was only 1.5 times on average. A shorter duration of treatment may result in a lower bacteriological curing rate and hereby an increased risk of recurrence and development of antibiotic resistance. However, Bennedsgaard et al. (2006) found no differences in the incidence of penicillin-resistant $S$. aureus in the milk from cows with high somatic cell counts in organic and conventional dairy farms in Denmark.

Combating of antibiotic resistance in animal production requires not only a reduction in the use of antibiotics but also a better understanding of the effects of $\mathrm{Zn}$ and $\mathrm{Cu}$ supplementation in animal diets in relation to antibiotic resistance. Resistance to $\mathrm{Zn}$ is often linked with resistance to methicillin in staphylococci, and $\mathrm{Zn}$ supplementation to animal feed may increase the proportion of multiresistant $E$. coli in the gut. Resistance to $\mathrm{Cu}$ in bacteria, in particular enterococci, is often associated with resistance to antimicrobial drugs like macrolides and glycopeptides (e.g. vancomycin) (Yazdankhah et al. 2014). The maximum content of $\mathrm{Zn}$ and $\mathrm{Cu}$ in the feed is regulated by EU legislation that applies to conventional as well as organic husbandry. However, for some age groups, the limits herein are too high compared to the need of the animals, and this is particularly true for organic monogastrics that in contrast to conventional monogastrics get a considerable part of their feed from outdoor areas (EGTOP 2015). Already more than 10 years ago, DG Sanco Scientific Committee (2003) stated that the high level of $170-\mathrm{mg} \mathrm{Cu} / \mathrm{kg}$ feed authorised for piglets not only covers their nutritional requirement but also act as an efficient growth promotor. In 2016, EFSA proposed a lowering of the maximum $\mathrm{Cu}$ contents for piglets from $170-$ to $25-\mathrm{mg} \mathrm{Cu} / \mathrm{kg}$ complete feed (EFSA 2016), and the same year, the 
maximum content of $\mathrm{Zn}$ in $\mathrm{mg} / \mathrm{kg}$ complete feed was lowered for several animal species (COM 2016).

\section{Overview of direct and indirectly derived effects of restricted use of antibiotics}

In summary, the restrictive use of antibiotics in organic livestock production has some direct positive effects on the public goods, i.e. on Human Health and Welfare (less antibiotic residues and antibiotic resistant bacteria in animal food products) and Nature and Biodiversity (avoiding negative effects on the composition of the soil and manure microbiota and insects). Moreover, the required management practices aimed at securing livestock health and welfare and preventing medicine needs impact animal health, environment and climate emissions (Fig. 3).

More space outdoors and access to grazing contribute positively to Human Health and Welfare, because the animal products have a healthier fatty acid composition due to grazing. However, these requirements result in both positive and negative effects on the Environment. Leaching of nitrate is lower on organic dairy farms due to larger areas with clover grass fields and lower stocking rates, but ammonia volatilisation and nitrate leaching are higher on organic pig and poultry farms.

\section{Discussion and conclusion}

As demonstrated above, the strict organic regulation on the use of pesticides and antibiotics as well as the compensating rules to make the use of pesticides and antibiotics redundant or minimal (the indirect effects) explains a large part of the impacts of organic farming on public goods. The two examples also demonstrate the synergies and dilemmas of organic farming in relation to the different public goods, as they are integral effects of the organic principles and specific rules. The requirements for crop rotation and limitations on fertiliser use together with the limited access to pesticides reinforce the need for organic crop management, which builds on prevention of weeds and pests through combinations of annual and perennial crops, growing of legumes for nitrogen fixation, nutrient recycling and catch crops, mechanical weeding and use of functional biodiversity. Likewise, the limitation on livestock medication is linked with requirements for more space indoors and outdoors per animal and access to outdoor areas with grazing and feeding of roughage - also to monogastrics - plus limitations in the use of feed additives including synthetic amino acids. These rules direct certain characteristics of livestock production including the design and use of outdoor areas, feeding strategies and feed use efficiency, crop rotations, manure handling and nutrient cycling.

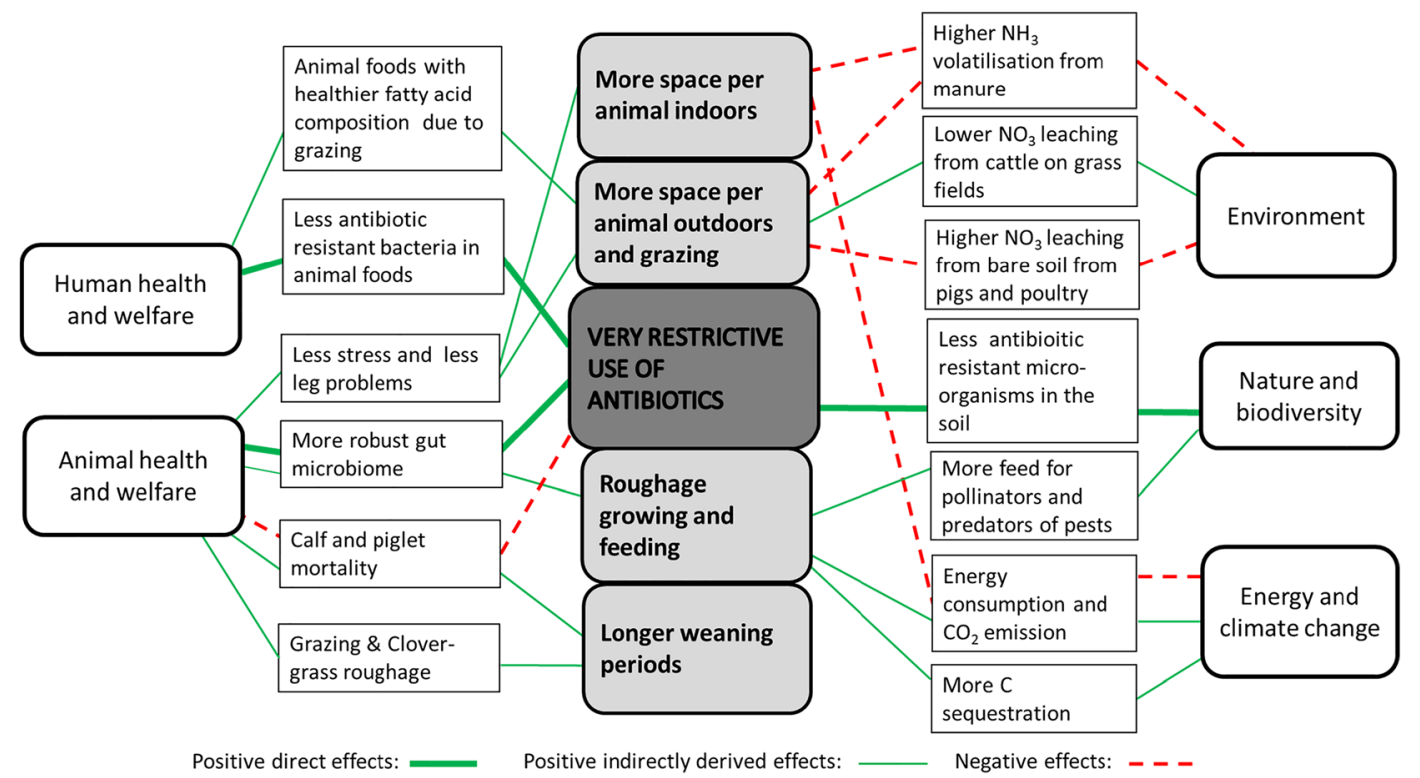

Fig. 3 Direct and indirect contribution of organic farming to public goods due to restrictive use of antibiotics plus compensating animal health and welfare promoting requirements 
The crop and livestock practices in combination influence the nutrient and feed use efficiencies, the crop and livestock yields, all of which have implications for the impact on public goods. However, the resulting characteristics of a specific farm - the farm type (cash crops, pigs, dairy, poultry or mixed production), the geographical location, the soil type and the strategies and daily management by the individual farmer also has great influence. Therefore, the effects on specific public goods will vary significantly between different organic farm types as well as within the farm types, which means that there is room for improvement of the farm management. A number of farm management tools have been developed over the last two decades for voluntary integration of animal health and welfare and other public goods in self-assessment tools for farmers (Halberg et al. 2005; Schader et al. 2014). Organic organisations and advisors in Denmark and other European countries promote the idea of using holistic sustainability assessment tools. This is also a main idea of the concept of Organic 3.0 (Arbenz et al. 2016). However, until now, there is little documentation that such an individual approach will have significant impact in terms of improving the contribution of organic farming to public goods. Another approach, also supported by the Danish organic organisations, is to strengthen and extend the rules for organic farming. At the moment, there are no specific requirements in the EU Organic Regulation or the Danish organic guidelines on organic farming as regards resource efficiency (including energy), climate change mitigation and contribution to nature and biodiversity. Therefore, the Danish organic farmer organisation plans to change policy in that direction (Økologisk Landsforening 2016).

Our analysis demonstrates that the requirements in organic agriculture on restrictive use of pesticides and antibiotics and the derived requirements and practices to compensate for that have direct, mostly positive impact on several public goods, especially on biodiversity and animal health and welfare. There seems to be a synergy between these effects, but there are also dilemmas, most notably between requirement for securing animal health and welfare with outdoor access and the environmental management. The analysis also shows that organic production may have very different impacts on policy focus areas where there are no specific requirements in the organic regulation, such as climate change mitigation. However, there are also other reasons for negative or no impact of organic farming. The challenges of ammonia and nitrate losses in many organic production systems compared to similar conventional seem to be caused by difficulties in nutrient management by manure application and biological $\mathrm{N}$ fixation in the crop rotation (Eriksen et al. 2014; Mikkelsen et al. 2014) and in avoidance of losses from the outdoor areas of pigs and poultry. This is mainly a technical question and a dilemma between animal health and welfare vs. resource efficiency and environment. Significant research and innovation efforts are currently focusing on how to ameliorate these problems by, e.g. introducing perennial vegetation in part of the outdoor areas for pigs and poultry, such as willow or poplar for bioenergy harvest (Jespersen et al. 2015; Steenfeldt 2015). Another focus of research is production of high-quality protein for monogastrics from alternative sources such as insects, marine biomass and green biomass to optimise the amino acid composition, which cannot be balanced by addition of synthetic amino acids as in conventional feeds. An integrated biorefinery system for production of highquality protein with subsequent bioenergy production from the residual fraction and recycling of the nutrients in the biogas effluent to cash crops could help in reducing the excess nutrient losses and GHG emission from organic pig and poultry production (MolinuevoSalces et al. 2015).

As regards health effects of organic diets, it is difficult to prove individual health effects from eating organic foods when comparing to conventional, product by product. The difference in climate impact and nutrient losses between organic and conventional agriculture is most often also modest when comparing product by product. Generally, the difference in climate impact and resource use between different food types is larger and more consistent with meat products having the higher impacts than between agricultural production systems. However, there might be wider effects of organic agriculture at food system level when considering the linkages between diet choice, production system and the combined results in terms of health, resource use and environmental impacts. A few Danish studies indicate that consumers who spend more than $10 \%$ of their food budget on organic food products also have a lower proportion of meat in their diets and a higher proportion of vegetables compared to consumers that buy mostly conventional food (Denver and Christensen 2015; Denver et al. 2007). Whilst the actual cause-effect of this relation - if general-is unclear, it is important in 
the light of the increased awareness of which farming systems are more sustainable, as this cannot be separated from the influence of peoples' choice of diets. The potential synergies in linking agri-environmental and climatic questions with dietary choices and human health (Tilman and Clark 2014) can become a strong driver for support to organic agriculture in a food system perspective. Another aspect of the food system approach is the perceived linkages with rural development and social and business innovations, which we did not include here (Jespersen 2015). Organic agriculture is often linked with new local cooperation networks involving organic farmers, small- and medium-scale organic processing plants and innovative marketing initiatives, either as direct marketing or through local retailers. It should be noted, however, that the vast majority of organic produce sold in Denmark finds its way to consumers via supermarkets and discount chains, which is an important factor behind the high average spending on organic food per capita in Denmark. Professionalisation of the organic organisations in Denmark has allowed them to act as intermediaries in connecting small, specialised producers of high-quality food and beverage with retailers, hereby to some degree counteracting the general trend towards larger farms.

The original knowledge synthesis (Jespersen 2015) and this paper was focused on assessing synergies and trade-offs related to organic farming in Denmark, but the literature reviews in relation to each topic also included international studies and reviews where relevant. Therefore, it is expected that the overall results may have general relevance for large parts of organic agriculture in Europe. Since most of the effects analysed are results of the EU Organic Regulation, ideas for strengthening particular aspects such as resource efficiency and climate change mitigation would be most efficiently addressed at a trans-European level. As a background for that similar assessments of synergies and dilemmas in the contribution of organic agriculture to public goods across Europe would be welcome. The demonstrated interlinkages between the effects on public goods have inspired the idea illustrated in the multitool (Fig. 1) that organic farming might be of special interest as seen from a public policy tool perspective. This idea has been discussed in different informal and formal meetings on organic agriculture, which is why we used this as an inspirational starting point for the knowledge synthesis (Jespersen 2015).

However, considerations for using organic agriculture as a public policy instrument in Denmark have been limited to acknowledging the lower nitrate losses from organic dairy farming and supporting organic (pesticide-free) agriculture on land directly above groundwater sources used for drinking water. So far, policy makers have not explicitly considered supporting organic agriculture as a single policy measure to achieve several public goods at the same time. This might be due to the single-issue focus on agrienvironment policy measures where policy makers most often analyse public goods measures independently of each other, e.g. how to reduce environmental impact of nitrogen, phosphorous and pesticides or measures for improvement of the biodiversity. With such a single-issue focus analysts may find supporting organic agriculture expensive compared to other more direct measures such as demanding catch crops in conventional farming. However, analysing the same objectives from an integrated perspective might point to organic agriculture as the most cost-effective policy option in areas where the demonstrated synergies are relevant. On the other hand, the idea of organic agriculture as a multitool in relation to public goods needs more evidence of the synergies between public goods effects in relation to specific organic farm types, farm sizes, soil types and geographical location as well as management. Moreover, the relevance of organic farming as a multitool in relation to public goods will depend on improvements - in particular as regards resource efficiency and climate change mitigation. Initiatives to better regulate and document such public goods effects could be important for securing the longterm support to organic agriculture. Besides, it would be relevant to discuss and update the formulation of the organic principles of the EU Organic Regulation and to evaluate how the specific requirements can be formulated to make the organic principles better translated into practice - especially as regards the organic requirements, which give rise to dilemmas in relation to the contribution of organic farming to public goods.

Acknowledgements The authors greatly acknowledge the financial support of the work from the Ministry of Environment and Food of Denmark.

Open Access This article is distributed under the terms of the Creative Commons Attribution 4.0 International License (http:// creativecommons.org/licenses/by/4.0/), which permits unrestricted use, distribution, and reproduction in any medium, provided you give appropriate credit to the original author(s) and the source, provide a link to the Creative Commons license, and indicate if changes were made. 


\section{References}

Andersen LW, Bruus M, Jensen TS, Marchi C, Topping C, Damgaard C, Olsen K, Dalgaard T, Strandberg B (2014) Øger økologisk landbrug biodiversiteten? Hovedkonklusioner fra REFUGIA-projektet. Særtillæg til ICROFS nyt september $2014 \mathrm{http}: / /$ icrofs.dk/fileadmin/icrofs/Nyhedsbreve/Refugia ICROFS_Nyt.pdf. Accessed on 6 Aug 2017

Anderson KE (2011) Comparison of fatty acid, cholesterol, and vitamin $\mathrm{A}$ and $\mathrm{E}$ composition in eggs from hens housed in conventional cage and range production facilities. Poult Sci 90:1600-1608

Anonymous (2015) Handlingsplan for husdyr-MRSA. 16 April $2015 \mathrm{http} / / \mathrm{mfvm} . \mathrm{dk} /$ nyheder/nyhed/nyhed/handlingsplantil-bekaempelse-af-husdyr-mrsa-1/. Accessed on 28 Apr 2017

Anonymous (2017) Aftale om Pesticidstrategi 2017-2021 af 21. April $2017 \mathrm{http}: / / \mathrm{mfvm} . \mathrm{dk} / \mathrm{fileadmin} / \mathrm{user}$ upload/MFVM/Publikationer/21-04-2017_ENDELIGT_AFTALEUDKAST.pdf. Accessed on 24 Apr 2017

Arbenz M, Gould D, Stopes C (2016) Organic 3.0 for truly sustainable farming \& consumption. $2^{\text {nd }}$ updated edition, 2016. IFOAM Organics International http://www.ifoam. bio/sites/default/files/organic3.0_v.2_web_0.pdf. Accessed on 28 Apr 2017

Arnott G, Ferris CP, O'Connell NE (2017) Review: welfare of dairy cows in continuously housed and pasture-based production systems. Animal 11:261-272

Aude E, Tybirk K, Pedersen MB (2003) Vegetation diversity of conventional and organic hedgerows in Denmark. Agric Ecosyst Environ 99:135-147

Baguer AJ, Jensen J, Krogh PH (2000) Effects of the antibiotics oxytetracycline and tylosin on soil fauna. Chemosphere 40: 751-757

Bártiková H, Podlipná R, Skálová L (2016) Veterinary drugs in the environment and their toxicity to plants. Chemosphere 144: 2290-2301

Bengtsson J, Ahnström J, Weibull A-C (2005) The effects of organic agriculture on biodiversity and abundance: a metaanalysis. J Appl Ecol 42:261-269

Bennedsgaard TW, Thamsborg SM, Aarestrup FM, Enevoldsen C, Vaarst M, Christoffersen AB (2006) Resistance to penicillin of Staphylococcus aureus isolates from cows with high somatic cell counts in organic and conventional dairy herds in Denmark. Acta Vet Scand 2006(48):24. https://doi. org/10.1186/1751-0147-48-24

Bennedsgaard TW, Klaas IC, Vaarst M (2010) Reducing use of antimicrobials - experiences from an intervention study in organic dairy herds in Denmark. Livest Sci 131:183-192

Bernhoft A, Clasen P-E, Kristoffersen AB, Torp M (2010) Less Fusarium infestation and mycotoxin contamination in organic than conventional cereals. Food Addit Contam 27(6):842852

Birkhofer K, Ekroos J, Corlett EB, Smith HG (2014) Winners and losers of organic cereal farming in animal communities across central and northern Europe. Biol Conserv 175:25-33

Blajet-Kosicka A, Twaruzek M, Kosicki R, Sibiorowska E, Grajewski J (2014) Co-occurrence and evaluation of mycotoxins in organic and conventional rye grain and products. Food Control 38:61-66
Bosselmann AS, Gylling M (2014) Notat-Miljømæssige konsekvenser ved den danske import af majs og soja til svinefoderproduktionen. IFRO, Københavns Universitet

Boutin C, Strandberg B, Carpenter D, Mathiassen SK, Thomas PJ (2014) Herbicide impact on non-target plant reproduction: what are the toxicological and ecological implications? Environ Pollut 185:295-306

Brandt KK, Amézquita A, Backhaus T, Boxall A, Coors A, Heberer T, Lawrence JR, Lazorchak J, Schönfeld J, Snape JR, Zhu Y-G, Topp E (2015) Ecotoxicological assessment of antibiotics: a call for improved considerations of microorganisms. Environ Int 85:189-205

Bruus M, Andersen HV, Løfstrøm P, Kjær C, Glasius M, Jensen B, Strandberg MT, Bak JL, Hansen KM, Bossi R (2008) Omfang og effekt af herbicidafdrift til læhegn. Bekæmpelsesmiddelforskning fra Miljøstyrelsen 120(2008): 1-86

Chiu YH, Afeiche MC, Gaskins AJ, Williams PL, Petrozza JC, Tanrikut C, Hauser R, Chavarro JE (2015) Fruit and vegetable intake and their pesticide residues in relation to semen quality among men from a fertility clinic, human reproduction. Vol 30:1342-1351. https://doi.org/10.1093 /humrep/dev064

Christensen BT, Rasmussen J, Eriksen J, Hansen EM (2009) Soil carbon storage and yields of spring barley following grass leys of different age. Eur J Agron 31:29-35

Christensen T, Olsen SB, Kærgård N, Dubgaard A (2014) Spørgeskemaundersøgelse om økologisk forbrug. Frederiksberg: Institut for Fødevare- og Ressourceøkonomi, Københavns Universitet. (IFRO Dokumentation; Nr. 2014/3)

COM (2011) Communication from the Commission to the European Parliament and the Council. Action plan against the rising threats from antimicrobial resistance. COM (2011) 748. Directorate General for Health and Consumers

COM (2016) Commission Implementing Regulation (EU) 2016/1095 of 6 July 2016 concerning the authorization of zinc acetate dihydrate, zinc chloride anhydrous, zinc oxide, zinc sulphate heptahydrate, zinc sulphate monohydrate, zinc chelate of amino acids hydrate, zinc chelate of protein hydrolysates, zinc chelate of glycine hydrate (solid) and zinc chelate of glycine hydrate (liquid) as feed additives for all animal species and amending Regulations (EC) No 1334/2003, (EC) No 479/2006, (EU) No 335/2010 and implementing Regulations (EU) No 991/2012 and (EU) No 636/2013

Council Directive 91/414/EEC (1991) Council Directive of 15 July 1991 concerning the placing of plant protection products on the market

Council Directive 91/676/EEC (1991) Council Directive of 12 December 1991 concerning the protection of waters against pollution caused by nitrates from agricultural sources (91/ 676/EEC)

Council Directive 98/83/EC (1998) Council Directive 98/83/EC of 3 November 1998 on the quality of water intended for human consumption

Crittenden SJ, Huerta E, de Goede RGM, Pulleman MM (2015) Earthworm assemblages as affected by field margin strips and tillage intensity: an on-farm approach. Eur J Soil Biol 66: 49-56

Crowder DW, Northfield TD, Strand MR, Snyder WE (2010) Organic agriculture promotes evenness and natural pest control. Nature 466:109-123 
DANMAP (2015) DANMAP (Danish Integrated Antimicrobial Resistance Monitoring Programme). Use of antimicrobial agents and occurrence of antimicrobial resistance in bacteria from food animals, food and humans in Denmark. (2015). http://www.danmap.org/downloads/reports.aspx Accessed on 18 Apr 2017

Danmarks Statistik (2017) Retrieval of data from the Bank of Statistics, Statistics Denmark as of 23.01.2017

DCE (2016) Denmark's National Inventory Report 2015 and 2016. Emission Inventories 1990-2014 - submitted under the United Nations Framework Convention on Climate Change and the Kyoto Protocol. Scientific Report from DCE-Danish Centre for Environment and Energy No. 189

Denver S, Christensen T (2010) Dokumentation af valgeksperiment og spørgeskema. Institut for Fødevare- og Ressourceøkonomi. http://orgprints.org/16699/2/16699.pdf. Accessed on 6 Aug 2017

Denver S, Christensen T (2015) Organic food and health concerns: a dietary approach using observed data. NJAS - Wageningen J Life Sci 74-75:9-15. https://doi.org/10.1016/j. njas.2015.05.001

Denver S, Christensen T, Krarup S (2007) Får økologiske forbrugere oftere 6 om dagen. Tidsskrift Landøkonomi 193(2):109-118

Department of Bioscience (2017) The Danish Redlist, Department of Bioscience, Aarhus University. http://bios.au. $\mathrm{dk} / \mathrm{en} / \mathrm{knowledge-exchange/til-jagt-og-vildtinteresserede/the-}$ danish-red-list/. Accessed on 6 Apr 2017

DG Sanco (2017) European Commission Pesticides Database. http://ec.europa.eu/food/plant/pesticides/eu-pesticidesdatabase/public/? event=homepage \&language $=$ EN . Accessed 18 Apr 2017

DG Sanco Scientific Committee (2003) Opinion of the Scientific Committee for Animal Nutrition on the use of copper in feedingstuffs, adopted on 19 February 2003

Directive 2009/128/EC (2009) Directive 2009/128/EC of the European Parliament and of the Council of 21. October 2009 establishing a framework for Community action to achieve the sustainable use of pesticides

DS Nyt (2016) Landmændene dyrkede flere vårafgrøder i 2016. Nyt fra Danmarks Statistisk Nr. 313, 12. juli 2016

Duval JE, Bareille N, Fourichon C, Madouasse A, Vaarst M (2016) Perceptions of French private veterinary practitioners' on their role inorganic dairy farms and opportunities to improve their advisory services for organic dairy farmers. Prev Vet Med 113:10-21

Edwards SG (2009a) Fusarium mycotoxin content of UK organic and conventional wheat. Food Addit Contam Part A 26(4): 496-506

Edwards SG (2009b) Fusarium mycotoxin content of UK organic and conventional oats. Food Addit Contam Part A 26(7): 1063-1069

EFSA (2016) Revision of the currently authorised maximum copper content in complete feed. EFSA J 14(8):e04563 9 August 2016

EFSA (2017) The 2015 European Union report on pesticide residues in food. EFSA J 15(4):4791 134 pp

EGTOP (2015) Expert Group for Technical Advice on Organic Production (EGTOP) Final Report Feed Mandate II (2015)

Ejrnæs R (2017) Personal communications. Senior Researcher, Aarhus University
EMA (2016) Sales of veterinary antimicrobial agents in 29 European countries in 2014. Trends from 2011 to 2014. Sixth ESVAC report. European Medicines Agency, 14 October 2016, EMA/61769/2016

EMA (2017) Antimicrobial resistance. European Medicines Agency http://www.ema.europa.eu/ema/index.jsp?curl= pages/special_topics/general/general_content_000439. jspAccessed on 18 Apr 2017

EMA and EFSA (2017) EMA and EFSA Joint Scientific Opinion on measures to reduce the need to use antimicrobial agents in animal husbandry in the European Union, and the resulting impacts on food safety (RONAFA). EFSA J 15(1):4666

Eriksen J (2001) Implications of grazing by sows for nitrate leaching, from grassland and the succeeding cereal crop. Grass Forage Sci 56:317-322

Eriksen J, Askegaard M, Tersbøl M (2014) Estimering af risiko for nitratudvaskning fra økologiske bedriftstyper samt undersøgelse og forslag til reducerende tiltag. Miljøprojekt 1566, 2014,Miljøstyrelsen

Ernst G, Emmerling C (2009) Impact of five different tillage systems on soil organic carbon content and the density, biomass, and community composition of earthworms after a ten year period. Eur J Soil Biol 45:247-251

EU Reg. 1305/2013 (2013) Regulation (EU) No. 1305/2013 of the European Parliament and of the Council of 17 December 2013 on support for rural development by the European Agricultural Fund for Rural Development (EAFARD) and repealing Council Regulation (EC) No. 1698/2005

EU Reg. 1307/2013 (2013) Regulation (EU) No. 1307/2013 of the European Parliament and of the Council of 17 December 2013 establishing rules for direct payments to farmers under support schemes within the framework of the Common Agricultural Policy and repealing Council Regulation(EC) No. 637/2008 and Council Regulation (EC) No 73/2009

EU Reg. 178/2002 (2002) Regulation (EC) No 178/2002 of the European Parliament and of the Council of 28 January 2002 laying down the general principles and requirements of food law, establishing the European Food Safety Authority and laying down procedures in matters of food safety

EU Reg. 396/2005 (2005) Regulation (EC) No. 396/2005 of the European Parliament and of the Council of 23 February 2005 on maximum residue levels of pesticides in or on food and feed of plant and animal origin and amending Council Directive 91/414/EEC

EU Reg. 834/2007 (2007) Regulation (EC) No 834/2007 (2007): Council regulation (EC) no. 834/2207 of 28 June 2007. http://eur-lex.europa.eu/legal-content/EN/TXT/PDF/?uri= CELEX:02007R0834-20130701\&qid=1416479300107 $\&$ from=EN. Accessed on 2 Jan 2017

EU Reg. 889/2008 (2008) Commission regulation (EC) no 889/ 2008 of 5 September 2008 with amendments. http://eur-lex. europa.eu/legal-content/EN/TXT/PDF/?uri=CELEX:02008 R0889-20161107\&from=EN. Accessed on 2 Jan 2017

European Commission (2017a) Agriculture and rural development. CAP and Rural development. Available on-line: https://ec.europa.eu/agriculture/organic/eu-funding/cap-andrural-development en

European Commission (2017b) Agriculture and rural development. The history of the common agricultural policy. Available on-line: https://ec.europa.eu/agriculture/capoverview/history_en. Accessed on July 2017 
Eurostat (2016) Pesticide sales statistics http://ec.europa. eu/eurostat/statistics-explained/index.php/Pesticide_sales statistics. Accessed on 6 Aug 2017

Fødevarestyrelsen (2015a) Kontrollen med pesticidrester i foder 2007-2014. November $2015 \mathrm{https}: / / \mathrm{www}$. foedevarestyrelsen.dk/SiteCollectionDocuments/Kemi\%20 og\%20foedevarekvalitet/Foder/Rapport\%20pesticider\%20 i\%20foder\%202007-2014_final\%2005-11-2015.pdf. Accessed on 6 Aug 2017

Fødevarestyrelsen (2015b) MRSA screeningundersøgelser 2015 h t t p s : / / w w w. foe d e vare s t y r e $1 \mathrm{sen}$. $\mathrm{dk} /$ SiteCollectionDocuments/Foder-\%20og\% 20 foedevaresikkerhed/Slutrapporter/Rapport-om-MRSAscreeningsundersoegelser-2015. Accessed on 22 Mar 2017

Fødevarestyrelsen (2016) Pesticidrester i Fødevarer 2015. Resultater fra den danske pesticidkontrol

Fødevarestyrelsen (2017) Det Økologiske Spisemærke. http://www.oekologisk-spisemaerke.dk/. Accessed on 26 Apr 2017

Graham DW, Knapp CW, Christensen BT, McCluskey S, Dolfing J (2016) Appearance of $\beta$-lactam resistance genes in agricultural soils and clinical isolates over the 20th century. Sci Rep 6:21550. https://doi.org/10.1038/srep21550

Halberg N (2012) Assessment of the environmental sustainability of organic farming: definitions, indicators and the major challenges. Can J Plant Sci 92(6):981-996

Halberg N, Van der Werf HMG, Basset-Mens C, Dalgaard RL, De Boer IJM (2005) Environmental assessment tools for the evaluation and improvement of European livestock production systems. Livest Prod Sci 96:33-50

Halberg N, Alrøe HF, Meldgaard M, Michelsen J (2008a) Development, growth, and integrity in the Danish organic sector. A knowledge synthesis on the opportunities and barriers for a continued development and market-based growth in production, processing, and sale of organic products. A white paper. International Centre for Research in Organic Food Systems, pp $58 \mathrm{http}: / /$ icrofs.dk/fileadmin/user upload/2008-Alroe_and_Halberg-Development_growth and_integrity_in_the_Danish_organic_sector_A_white paper.pdf. Accessed on 6 Aug 2017

Halberg N, Dalgaard R, Olesen JE, Dalgaard T (2008b) Energy self-reliance, net-energy production and GHG emissions in Danish organic cash crop farms. Renewable Agric Food Syst 23(1):30-37

Halberg N, Hermansen JE, Kristensen IS, Eriksen J, Tvedegaard $\mathrm{N}$, Petersen BM (2010) Impact of organic pig production systems on $\mathrm{CO}_{2}$ emission, $\mathrm{C}$ sequestration and nitrate pollution. Agron Sustain Dev 30:721-731

Hammer TJ, Fierer N, Hardwick B, Simojoki A, Slade E, Taponen J, Viljanen H, Roslin T (2017) Treating cattle with antibiotic affects greenhouse gas emissions, and microbiota in dung and dung beetles. Proc R Soc B Biol Sci 283:20160150. https://doi.org/10.1098/rspb.2016.0150

Hanley ME, Franco M, Dean CE, Franklin EL, Harris HR, Haynes AG, Rapson SR, Rowse G, Thomas KC, Waterhouse BR, Knight ME (2011) Increased bumblebee abundance along the margins of a mass flowering crop: evidence for pollinator spill-over. Oikos 120:1618-1624

Hass U, Boberg J, Christiansen S, Jacobsen PR, Vinggaard AM, Taxvig C, Poulsen ME, Herrmann SS, Jensen BH, Petersen A, Clemmensen LKH, Petersen MA (2012) Adverse effects on sexual development in rat offspring after low dose exposure to a mixture of endocrine disrupting pesticides. Reprod Toxicol 34:261-274. https://doi.org/10.1016/j. reprotox.2012.05.090

Hegelund L, Sørensen JT, Kjær JB, Kristensen IS (2005) Use of range area in organic egg production systems: effects of climate factors, flock size, age and artificial cover. Br Poult Sci 46:1-8

Henriksen CI (2013) Bumblebees and solitary bees - effects of farming and semi-natural habitats. $\mathrm{PhD}$. Thesis, University of Copenhagen

Hole DG, Perkins AJ, Wilson JD, Alexander IH, Grice PV, Evans AD (2005) Does organic farming benefit biodiversity. Biol Conserv 122:113-130

IFOAM (2005) Principles of organic agriculture http://www. ifoam.bio/sites/default/files/poa_english_web.pdf. Accessed 6 Aug 2017

Ivemeyer S, Knierim U, Waiblinger S (2011) Effect of humananimal relationship and management on udder health in Swiss dairy herds J. Dairy Sci 94:5890-5902

Jechalke S, Heuer H, Siemens J, Amelung W, Smalla K (2014) Fate and effects of veterinary antibiotics in soil. Trends Microbiol 22(9):536-545

Jensen AN, Aabo S (2014) SafeOrganic - restrictive use of antibiotics in organic animal farming - a potential for safer, high quality products with less antibiotic resistant bacteria. http://orgprints.org/27980/. Accessed on 6 Aug 2017

Jensen KL, Pedersen E (2015) Status og udvikling i dansk økologi i perioden 2005-2014 (status and development of the Danish organic sector, 2005-2014). In: Jespersen, L.M. (2015) Økologiens bidrag til samfundsgoder. ICROFS. 406 pp http://icrofs.dk/fileadmin/icrofs/Diverse_materialer_til_ download/Vidensynte_WEB_2015_Fuld_laengde_400_ sider.pdf. Accessed on $\overline{6}$ Aug 2017

Jespersen LM (Ed.) (2015) Økologiens bidrag til samfundsgoder. Vidensyntese 2015. ICROFS. 406 pp. http://icrofs. $\mathrm{dk} /$ fileadmin/icrofs/Diverse_materialer_til_ download/Vidensynte_WEB_2015_Fuld_laengde_400_ sider.pdf. Accessed on 6 Aug 2017

Jespersen LM, Krabsen J, Kristensen H, Halberg N (Eds.) (2015) The contribution of organic farming to public goods in Denmark. ICROFS. $15 \mathrm{pp}$ http://icrofs.dk/fileadmin/user upload/Knowledge_synthesis___short_edition.pdf. Accessed on 6 Aug 2017

Knight ME, Osborne JL, Sanderson RA, Hale RJ, Martin AP, Goulson D (2009) Bumblebee nest density and the scale of available forage in arable landscapes. Insect Conserv Divers 2:116-124

Knudsen MT (2011) Environmental assessment of imported organic products. Ph.D. Thesis, KU-Life, Copenhagen

Knudsen MT, Hermansen JE, Halberg N, Andreasen, L, Williams A (2011) Life cycle assessment of organic food and farming systems: methodological challenges related to greenhouse gas emissions and carbon sequestration. In: FAO: Agriculture and Climate change mitigation. A report of the round table on organic agriculture and climate change. December 2011, Rome, Italy, pp. 33-60

Knudsen MT, Meyer-Aurich A, Olesen JE, Chirinda N, Hermansen JE (2014) Carbon footprints of crops from organic and conventional arable crop rotations using a life cycle 
assessment approach. J Clean Prod 64:609-618. https://doi. org/10.1016/j.jclepro.2013.07.009

Köhl L, Oehl F, van der Heijden MGA (2014) Agricultural practices indirectly influence plant productivity and ecosystem services through effects on soil biota. Ecol Appl 24:1842-1853

Kongsted H, Sørensen JT (2017) Lesions found at routine meat inspection on finishing pigs are associated with the pig production system. Vet J 223:21-26. https://doi.org/10.1016/j. tvj1.2017.04.016

Kristensen IS, Hermansen JE (2008) Næringsstofbalancer på bedriftsniveau til forenklet regulering af landbrugets næringsstof forbug og-overskud. (Farm level nutrient balances). Report to the Food and Agriculture Ministry. $36 \mathrm{pp}$

Kristensen T, Mogensen L, Knudsen MT, Hermansen JE (2011) Effect of production system and farming strategy on greenhouse gas emissions from commercial dairy farms in a life cycle approach. Livest Sci 140:136-148

Landbrug \& Fødevarer (2016) Stor vækst i antallet af økologiske landmænd. Press release of 28 Oct. 2016. http://www.lf. $\mathrm{dk} /$ aktuelt/nyheder/2016/oktober/stor-vaekst-i-antallet-afoekologiske-landmaend\#.WQmw3OXyi70. Accessed 27 Mar 2017

Landbrugs- og Fiskeristyrelsen (2017) Vejledning om økologisk jordbrugsproduktion, april 2017 http://lfst.dk/fileadmin/user_ upload/NaturErhverv/Filer/Indsatsomraader/Oekologi/ Jordbrugsbedrifter/Vejledning_til_oekologisk jordbrugsproduktion/Okologivejledning_Āpril_2017.pdf. Accessed on 6 Aug 2017

Larsen MK, Andersen KK, Kaufmann N, Wiking L (2014) Seasonal variation in the composition and melting behavior of milk fat. J Dairy Sci 98(8):4703-4712

Lu C, Warchol KM, Callahan RA (2014) Sub-lethal exposure to neonicotinoids impaired honey bees winterization before proceeding to colony collapse disorder. Bull Insectol 67(1): 125-130

Lundsgaard R, Nygaard T, Ogstrup L, Damm BI, Fenger NA, Holmstrup G (eds) (2016) Sådan ligger landbruget — tal om landbruget 2015. Danmarks Naturfredningsforening og Dyrenes Beskyttelse, København

Malaj E, von der Ohe PC, Grote M, Kuhne R, Mondy CP, Usseglio-Polatera P, Brack W, Schafer RB (2014) Organic chemicals jeopardize the health of freshwater ecosystems on the continental scale. Proc Natl Acad Sci U S A 111(26): 9549-9554. https://doi.org/10.1073/pnas.1321082111

Marti R, Scott A, Tien Y-C, Murray R, Sabourin L, Zhang Y, Topp $E$ (2014) Impact of manure fertilization on the abundance of antibiotic-resistant bacteria and frequency of detection of antibiotic resistance genes in soil and on vegetables at harvest. Appl Environ Microbiol 79(18):5701-5709

Meier MS, Stoessel F, Jungbluth N, Juraske R, Schader C, Stolze M (2015) Environmental impact of organic and conventional agricultural products - are the differences captured by life cycle assessment? J Environ Manag 149:193-208

Mie A. and Wivstad M. (2015) Organic food-food quality and potential health effects. A review of current knowledge, and a discussion of uncertainties. SLU, EPOK, Uppsala

Mikkelsen MH, Albrektsen R, Gyldenkærne S (2014) Danish emission inventories for agriculture. Inventories 1985-2011. Scientific Report from DCE_-Danish Centre for Environment and Energy, Aarhus University, No. 108. 142 pp
Miljø- og Fødevareministeriet (2016a) Alle danskere kender Ømærket. http://mfvm.dk/nyheder/nyhed/nyhed/alledanskere-kender-oe-maerket/. Accessed on 26 Apr 2017

Miljø- og Fødevareministeriet (2016b) Bekendtgørelse om vandkvalitet og tilsyn med vandforsyningsanlæg. Bekendtgørelse nr. 802 af 01/06/2016 (in force)

Miljøministeriet (2012) Beskyt vand, natur og sundhedSprøjtemiddelstrategi 2013-2015. 2012/2013:7

Miljøstyrelsen (2016) Sprøjtemiddelrester i vandværkernes indvindingsboringer og i grundvandsovervågning i 2014 fordelt på forbudte, regulerede og godkendte stoffer. Notat af 17 . marts 2016

Miljøstyrelsen (2017) Bekæmpelsesmiddelstatistik 2015. Orientering fra Miljøstyrelsen No. 17, 2017

Ministerierne for Miljø og Fødevarer (2004) Pesticidplan 20014 2009 for nedsættelse af pesticidanvendelsen og pesticidbelastningen. Miljøministeriet og Fødevareministeriet

Molinuevo-Salces B, Santamaria M, Kiel P, Uellendahl H, Lübeck M (2015) OrganoFinery: From green crops to proteins, energy and fertiliser. Poster at: 11th International Conference on Renewable Resources \& Biorefineries, York, June 3-5 2015. http://orgprints.org/29232/. Accessed on 24 August 2017

Mondelaers K, Aertsen J, Huylenbroeck GV (2009) A metaanalysis of the differences in environmental impacts between organic and conventional farming. Br Food J 111(19):10981119

Myers JP, Antoniou MN, Blumberg B, Carroll L, Colborn T, Everett LG, Hansen M, Landrigan PJ, Lanphear BP, Mesnage R, Vandenberg LN, Vom Saal FS, Welshons WV, Benbrook CM (2016) Concerns over use of glyphosate-based herbicides and risks associated with exposures: a consensus statement. Environ Health 15:19. https://doi.org/10.1186 /s12940-016-0117-0

NaturErhvervstyrelsen (2016) Statistik over økologiske jordbrugsbedrifter 2015-Autorisation \& Produktion. Juli 2016

Naturstyrelsen (2015) Indsatsområder inden for sprøjtemiddelfølsomme indvindingsområder. Miljøministeriet. http://naturstyrelsen.dk/media/133632 /indsatsomraader-for-sproejtemiddelfoelsommeindvindingsomraader.pdf. Accessed on 6 Apr 2017

Nielsen AH, Kristensen IS (2005) Nitrogen and phosphorus surpluses on Danish dairy and pig farms in relation to farm characteristics. Livest Prod Sci 96:97-107

O’Connor A, Sargeant J (2015) Research synthesis in veterinary science: narrative reviews, systematic reviews and meta-analysis. Vet J 206:261-267

OECD (2015) Public goods and externalities. Agri-environmental policy measures in selected OECD countries. http://www. oecd.org/tad/public-goods-and-externalities9789264239821-en.htm. Accessed on 6 Aug 2017

Oehl F, Sieverding E, Mäder P, Dubois D, Ineichen K, Boller T, Wiemken A (2004) Impact of long-term conventional and organic farming on the diversity of arbuscular mycorrhizal fungi. Oecologia 138:574-583

Økologisk Landsforening (2016) 10-punkts plan for en grønnere landbrugs- og fødevarepolitik-og meget mere økologi. Økologisk Landsforening 2016

Ollivier J, Schacht D, Kindler R, Groeneweg J, Engel M, Wilke BM, Kleineidam K, Schloter M (2013) Effects of repeated application of sulfadiazine contaminated pig manure on the 
abundance and diversity of ammonia and nitrite oxidizers in the root-rhizosphere complex of pasture plants under field conditions. Front Microbiol 4:22. https://doi.org/10.3389 /fmicb.2013.00022

Olsson A-C, Jeppesen K-H, Botermans J, Hv W, Andersson M, Bergsten C, Svendsen J (2014) Pen hygiene, N, P and K budgets and calculated nitrogen emission for organic growing-finishing pigs in two different housing systems with and without pasture access. Livest Sci 165:138-146

Österberg J, Wingstrand A, Jensen AN, Kerouanton A, Cibin V, Barco L, Denis D, Aabo S, Bengtsson B (2016) Antibiotic resistance in Escherichia coli from pigs in organic and conventional farming in four European countries. PLoS One 11(6):e0157049. https://doi.org/10.1371/journal. pone. 0157049

Peigné J, Cannavaciuolo M, Gautronneau Y, Aveline A, Giteau JL, Cluzeau D (2009) Earthworm populations under different tillage systems in organic farming. Soil Tillage Res 104: 207-214

Petersen S, Axelsen JA, Tybirk K, Aude E, Vestergaard P (2006) Effects of organic farming on field boundary vegetation in Denmark. Agric Ecosyst Environ 113:302-306

Petersen A, Jensen BH, Andersen JH, Poulsen ME, Christensen T, Nielsen E (2013) Pesticide residues 2004-2011. Results from the period 2004-2011. National Food Institute, Technical University of Denmark. http://www.food.dtu.dk/english//media/Institutter/Foedevareinstituttet/Publikationer/Pub2013/Pesticide-residues-results-2004-2011.ashx. Accessed on 6 Aug 2017

Popowska M, Rzeczycka M, Miernik A, Krawczyk-Balska A, Walsh F, Duffy B (2012) Influence of soil use on prevalence of tetracycline, streptomycin, and erythromycin resistance and associated resistance genes. Antimicrob Agents Chemother 56:1434-1443

Rasmussen JJ, Wiberg-Larsen P, Baattrup-Pedersen A, McKnight US, Cedergreen N, Kreuger J, Jacobsen D, Friberg N (2015) The legacy of pesticide pollution: an overlooked factor in current risk assessments of freshwater systems. Water Res 84 : 25-32

Raundal P, Nielsen J, Flagstad P (2017) Kalvedødelighed i Danmark. Landbrugsinfo, SEGES. https://www. landbrugsinfo.dk/Kvaeg/Tal-om-kvaeg/Sider/pif001 tabel12. aspx. Accessed on 18 Apr 2017

Reiten M (2014) Assessing animal welfare in dairy calves 0180 days. Master thesis, Aarhus University

Rosenquist H, Sandøe P, Tveit G, Winstrand A, Aabo S (2009) Fremtidens fødevaresikkerhed-nye veje mod sikrere kød i Danmark. Center for Bioetik og Riskovurdering

Säle V, Aguilera P, Laczko E, Mäder P, Berner A, Zihlmann U, van der Heijden MGA, Oehl F (2015) Impact of conservation tillage and organic farming on the diversity of arbuscular mycorrhizal fungi. Soil Biol Biochem 84:38-52

Samuelson PA (1954) The pure theory of public expenditure. Rev Econ Stat 36:387-389 https://www.ses.unam. $\mathrm{mx} /$ docencia/2007II/Lecturas/Mod3_Samuelson.pdf . Accessed on 6 Aug 2017

Samuelson PA (1955) Diagrammatic exposition of theory of public expenditure. Rev Econ Stat 37:350-356 https://courses. cit.cornell.edu/econ335/out/samuelson_diag.pdf. Accessed on 6 Aug 2017
Schader C, Grenz J, Meier MS, Stolze M (2014) Scope and precision of sustainability assessment approaches to food systems. Ecol Soc 19:42. https://doi.org/10.5751/ES-06866190342

Schjønning P, de Jonge LW, Munkholm LJ, Moldrup P, Christensen BT, Olesen JE (2012) Drivers for dispersibility and soil friability - test of the clay carbon saturation concept. Vadose Zone J 11. doi:https://doi.org/10.2136/vzj2011.0067

Schwendel BH, Wester TJ, Morel PCH, Tavendale MH, Deadman C, Shadbolt NM, Otter DE (2015) Invited review: organic and conventionally produced milk. An evaluation of factors influencing milk composition. Journal of Diary Science 98: $721-746$

Shapira N (2010) Every egg may have a targeted purpose: toward a differential approach to egg according to composition and functional effect. Worlds Poult Sci J 66:271-284

Song J, Rensing C, Holm PE, Virta M, Brandt KK (2017) Comparison of metals and tetracycline as selective agents for development of tetracycline resistant bacterial communities in agricultural soil. Environ Sci Technol 51:3040-3047

Sørensen JT (2015) Animal welfare in organic pig production. In: Proceedings International Conference on Pig Welfare: improving pig welfare-what are the way forward? Copenhagen Denmark 29-30 April 2015, 30-33

Sørensen JT, Pedersen LJ (2013) Status, årsager og udfordringer I forhold til løsning af forhøjet dødelighed hos økologiske pattegrise. (status, reasons and challenges in relation to increased piglet mortality in organic pig production). DCA rapport nr. 21, Aarhus University. http://dca.au. $\mathrm{dk} /$ fileadmin/DJF/DCA/Pattegrisedoedelighed.pdf . Accessed 18 Apr 2017

Sørensen MT, Poulsen HD, Højberg O (2014) Memorandum on "The feeding of genetically modified glyphosate resistant soy products to livestock". DCA-Danish Centre for Food and Agriculture, Aarhus University, Denmark. 4 February 2014

Średnicka-Tober D, Barański M, Gromadzka-Ostrowska J, Skwarło-Sońta K, Rembiałkowska E, Hajslova J, Schulzova V, Çakmak I, Öztürk L, Królikowski T, Wiśniewska K, Hallmann E, Baca E, Eyre M, Steinshamn H, Jordon T, Leifert C (2013) Effect of crop protection and fertilization regimes used in organic and conventional production systems on feed composition and physiological parameters in rats. J Agric Food Chem 61:1017-1029

Stagnari F, Perpetuini G, Tofalo R, Campanelli G, Leteo F, Vella UD, Schirone M, Suzi G, Pisante M (2014) Long term impact of farm management and crops on soil microorganisms assessed by combined DGGE and PLFA analyses. Front Microbil 5:644

Statens Seruminstitut (2017) Smitteberedskab: Blodforgiftninger og dødsfald. http://www.ssi.dk/Smitteberedskab/Viden\%20 og $\% 20 \mathrm{raad} \% 20 \mathrm{om} \% 20 \mathrm{MRSA} /$ Generelt $\% 20 \mathrm{om} \% 20$ MRSA/MRSA $\% 20$ infektioner/Blodforgiftninger $\% 20$ og $\% 20$ dodsfald.aspx. Accessed on 24 Apr 2017

Steenfeldt S (2015) Bedre øko-kyllinger med nye genotyper og fodringsstrategier. (Improved organic chicken with new genotypes and feeding strategies) Økologi \& Erhverv, 9 October 2015, 575, p. 11. Available on-line: http://icrofs. $\mathrm{dk} / \mathrm{en} /$ research/danish-research/organic-rdd-2/multichick/ Accessed on 6 Aug 2017 
STOA (2016) Human health implications of organic food and organic agriculture. European Parliamentary Research Service, Scientific Foresight Unit (STOA), December 2016

Tilman D, Clark M (2014) Global diets link environmental sustainability and human health. Nature 515:518-522. https://doi.org/10.1038/nature.13959

Tuck SL, Winqvist C, Mota F, Ahnström J, Turnbull LA, Bengtsson J (2014) Land-use intensity and the effects of organic farming on biodiversity: a hierarchical meta-analysis. J Appl Ecol 51:746-755

Tuomisto HL, Hodge ID, Riodan P, Macdonald DW (2012) Does organic farming reduced environmental impact? - a metaanalysis of European research. J. Environ Manag 112:309320

Larsen, VAA, Kongsted AG, Kristensen IS (2000) Frilandssohold - balancer på mark og bedriftsniveau. (Farm and field nutrient balances in outdoor sow production) In: Sommer, S.G. \& Eriksen, J. (eds). Næringsstofudnyttelse fra stald til mark i økologisk jordbrug. FØJO rapport no. 7, 67-74

Vaarst M, Thamsborg SM, Bennedsgaard TW, Houe H, Enevoldsen C, Aarestrup FM, De Snoo A (2003) Organic dairy farmers decision making in the first 2 years after conversion in relation to mastitis treatments. Livest Sci 80:109-120
Valyi K, Rillig MC, Hempel S (2014) Land-use intensity and host plant identity interactively shape communities of arbuscular mycorrhizal fungi in roots of grassland plants. New Phytol 205:1577-1586. https://doi.org/10.1111/nph.13236

Web Finance Inc. (2017) Business dictionary. http://www. businessdictionary.com/definition/public-good.html. Accessed on 18 Apr 2017

Wezel A, Bellon S, Doré T, Francis C, Vallod D, David C (2009) Agroecology as a science, a movement and a practice. A Review. Agron Sustain Dev 29:503-515. https://doi. org/10.1051/agro/2009004

Wingstrand A, Struve T, Lundsby K, Vigre H, Emborg HD, Sørensen AIV, Jensen VF (2010) Antibiotikaresistens og forbrug i slagtesineproduktionen i: Fremtidens fødevaresikkerhed - nye veje mod sikrere kød i Danmark. Center for Bioetik og Risikovurdering: pp. 98-106

Yazdankhah S, Rudi K, Bernhoft A (2014) Zinc and copper in animal feed-development of resistance and co-resistance to antimicrobial agents in bacteria of animal origin. Microb Ecol Health Dis 25:25862. https://doi.org/10.3402/mehd. v25.25862 